\title{
Chemical composition of free tropospheric aerosol for PM1 and coarse mode at the high alpine site Jungfraujoch
}

\author{
J. Cozic ${ }^{1}$, B. Verheggen ${ }^{1,}$, E. Weingartner ${ }^{1}$, J. Crosier ${ }^{2}$, K. N. Bower ${ }^{2}$, M. Flynn ${ }^{2}$, H. Coe ${ }^{2}$, S. Henning ${ }^{3}$, \\ M. Steinbacher ${ }^{4}$, S. Henne ${ }^{4}$, M. Collaud Coen ${ }^{5}$, A. Petzold ${ }^{6}$, and U. Baltensperger ${ }^{1}$ \\ ${ }^{1}$ Laboratory of Atmospheric Chemistry, Paul Scherrer Institut, 5232 Villigen PSI, Switzerland \\ ${ }^{2}$ School of Earth, Atmospheric and Environmental Sciences, University of Manchester, M13 9PL, UK \\ ${ }^{3}$ Leibniz-Institute for Tropospheric Research, 04318 Leipzig, Germany \\ ${ }^{4}$ Empa, Laboratory for Air Pollution/Environmental Technology, 8600 Dübendorf, Switzerland \\ ${ }^{5}$ Federal Office of Meteorology and Climatology, MeteoSwiss, Aerological Station, 1530 Payerne, Switzerland \\ ${ }^{6}$ Institute for Atmospheric Physics, German Aerospace Centre, 82234 Wessling, Germany \\ * currently at: Energy research Centre of the Netherlands ECN, P.O. Box 1, 1755 ZG Petten, The Netherlands
}

Received: 6 July 2007 - Published in Atmos. Chem. Phys. Discuss.: 17 August 2007

Revised: 20 November 2007 - Accepted: 21 December 2007 - Published: 31 January 2008

\begin{abstract}
The chemical composition of submicron (fine mode) and supermicron (coarse mode) aerosol particles has been investigated at the Jungfraujoch high alpine research station ( $3580 \mathrm{~m}$ a.s.l., Switzerland) as part of the GAW aerosol monitoring program since 1999 . A clear seasonality was observed for all major components throughout the period with low concentrations in winter (predominantly free tropospheric aerosol) and higher concentrations in summer (enhanced vertical transport of boundary layer pollutants). In addition, mass closure was attempted during intensive campaigns in March 2004, February-March 2005 and August 2005. Ionic, carbonaceous and non-refractory components of the aerosol were quantified as well as the PM1 and coarse mode total aerosol mass concentrations. A relatively low conversion factor of 1.8 for organic carbon (OC) to particulate organic matter $(\mathrm{OM})$ was found in winter (FebruaryMarch 2005). Organics, sulfate, ammonium, and nitrate were the major components of the fine aerosol fraction that were identified, while calcium and nitrate were the only two measured components contributing to the coarse mode. The aerosol mass concentrations for fine and coarse mode aerosol measured during the intensive campaigns were not typical of the long-term seasonality due largely to dynamical differences. Average fine and coarse mode concentrations during the intensive field campaigns were $1.7 \mu \mathrm{g} \mathrm{m}^{-3}$ and $2.4 \mu \mathrm{g} \mathrm{m}^{-3}$ in winter and $2.5 \mu \mathrm{g} \mathrm{m}^{-3}$ and $2.0 \mu \mathrm{g} \mathrm{m}^{-3}$ in summer, respectively. The mass balance of aerosols showed higher contributions of calcium and nitrate in the coarse mode during Saharan dust events (SDE) than without SDE.
\end{abstract}

Correspondence to: E. Weingartner

(ernest.weingartner@psi.ch)

\section{Introduction}

Atmospheric aerosol particles play an important role in the global radiation balance. The chemical composition and size distribution of the aerosol are important in quantifying these radiative effects, through influencing absorption and scattering. The size and composition also influence the hygroscopic properties of the aerosol particles and their ability to act as cloud condensation nuclei, and therefore affect cloud formation. Aerosol particles can also participate in heterogeneous reactions in the atmosphere, which are both composition and morphology dependent.

Measurements of size resolved chemical information provide information on the sources of aerosol particles. Primary/secondary and anthropogenic/natural aerosol particles can have significant chemical and physical differences. Aerosols are often separated into a coarse fraction (particles with a diameter $d>1 \mu \mathrm{m}$ ) and a fine fraction (PM1; $d<1 \mu \mathrm{m}$ ) during sampling. Primary aerosol refers to particles that are directly released into the atmosphere in the particle phase. Primary natural aerosol such as sea-salt, dust or volcanic ash particles are typically found in the coarse mode. Primary anthropogenic particles have various sources (black carbon (BC) for example is emitted by combustion processes) and is often found primarily in the fine mode. Secondary aerosol is formed by the transformation of gaseous precursors of either natural or anthropogenic origin into condensable material. For example, sulfate can be found as natural secondary aerosol originating from the oxidation of dimethyl sulfide released from marine plankton (Charlson et al., 1987), or anthropogenic secondary aerosol from the oxidation of $\mathrm{SO}_{2}$ (Colbeck, 1998) which is emitted in large concentrations

Published by Copernicus Publications on behalf of the European Geosciences Union. 
from fossil fuel combustion. Automobiles, industry, cooking and combustion are examples of anthropogenic sources of aerosol precursor gases. Secondary aerosol typically represents the majority of the fine particle mass (Turpin and Huntzicker, 1995).

The main constituents of fine atmospheric aerosol are inorganic ions, organic compounds and to a lesser extent black carbon (BC) otherwise known as elemental carbon (EC) (Krivacsy et al., 2001). While inorganic ion species and their concentrations have been determined at many locations around the world, data for carbonaceous compounds are rather limited due to the lack of instrumentation allowing for an artifact free quantification of the organic fraction. Recently new instrumentation (aerosol mass spectrometry, thermal-optical carbonaceous analyzers) has become available, allowing for the quantitative determination of the organic fraction. These measurements show that organic material comprises the dominant fraction of the fine aerosol in various environments (Zhang et al., 2007).

Knowledge of the chemical composition of atmospheric aerosol is important to assess its impact on the environment. Here we present long-term measurements of the chemical composition of coarse and fine mode aerosol particles from 1999 to 2006 at the Jungfraujoch high-alpine site in the Swiss Alps. The mass closure for PM1 and coarse mode aerosol was also investigated during a series of intensive field measurements. Following instrument intercomparisons, mass fractions of the various components for different seasons and aerosol types are discussed as well as their partitioning into the different size fractions.

\section{Site, sampling and analysis}

Measurements have been performed as part of the Global Atmosphere Watch (GAW) aerosol program of the World Meteorological Organization since 1999 and more intensively during Cloud and Aerosol Characterization Experiments (CLACE) at the Jungfraujoch high-alpine research station in Switzerland. The intensive field campaigns took place in March 2004, from mid July to end of September 2004, from mid February to mid March 2005 and in August 2005.

\subsection{Jungfraujoch station}

The Jungfraujoch (JFJ) site is located on an exposed mountain saddle in the Swiss Alps at 3580 ma.s.1. Atmospheric aerosols and gases have been measured at the JFJ within the GAW program for over a decade. The station is regularly engulfed in clouds (37\% of the time based on a year long survey by Baltensperger et al. (1998)). Due to its elevation, the site is only weakly influenced by local anthropogenic sources. These characteristics make the Jungfraujoch site a well suited ground based location to investigate continental background aerosols and clouds.
Measured aerosol parameters at the Jungfraujoch exhibit a strong seasonal cycle with a maximum in summer and a minimum in winter. In summer, the site is influenced by injections of planetary boundary layer air during afternoons when solar insolation is high or during periods of frontal activity, leading to variations in the concentrations and properties of the aerosol measured. Reduced solar heating in winter reduces the extent of vertical mixing and results in substantially lower aerosol concentrations for longer periods (Lugauer et al., 1998; Weingartner et al., 1999; Henne et al., 2005). Under these circumstances, the site is deemed representative of the lower free troposphere above a continental area. More information on the Jungfraujoch site and the long-term aerosol measurements can be found in Baltensperger et al. (1997) and Collaud Coen et al. (2007). Table 1 summarizes the different types of instruments operated during the different campaigns.

\subsection{Inlet}

The standard GAW total aerosol inlet was used at the JFJ. It is heated to $25^{\circ} \mathrm{C}$ to evaporate cloud droplets and ice crystals at an early stage of the sampling process (GAW, 2003) and has been designed to sample cloud droplets smaller than $40 \mu \mathrm{m}$ at a wind speed up to $20 \mathrm{~m} \mathrm{~s}^{-1}$ (Weingartner et al., 1999). The aerosol sample thus consists of aerosols incorporated into cloud droplets, ice crystals, and un-activated (interstitial) aerosols. Behind the inlet, the aerosol particles are sampled at laboratory room temperature under dry conditions (relative humidity $<20 \%$ ).

\subsection{Black carbon measurements}

The Multi-Angle Absorption Photometer (MAAP, Thermo ESM Andersen) (Petzold and Schonlinner, 2004) measures the transmitted and backscattered light intensity from a defined source $(\lambda=630 \mathrm{~nm})$ that is incident on a fiber filter through which air is also drawn. The particle light absorption coefficient $b_{\mathrm{abs}}$ is obtained from a radiative transfer scheme which corrects for artifacts caused by the interaction of the light with the filter material. The instrument is used to measure the black carbon mass concentration (BC) in real time. Black carbon (BC) is the most efficient lightabsorbing aerosol species in the visible spectral range. Thus, the aerosol light absorption in the visible spectral range is highly correlated with the concentration of black carbon. The relationship between the aerosol absorption coefficient $b_{\text {abs }}$ $\left(\mathrm{m}^{-1}\right)$ and the corresponding black carbon mass concentration $\mathrm{BC}\left(\mathrm{g} \mathrm{m}^{-3}\right)$ is established by a mass absorption efficiency $\sigma_{\mathrm{abs}, \mathrm{BC}}\left(\mathrm{m}^{2} \mathrm{~g}^{-1}\right)$ via the relationship

$b_{\mathrm{abs}}=\mathrm{BC} \cdot \sigma_{\mathrm{abs}, \mathrm{BC}}$

where $\sigma_{\mathrm{abs}, \mathrm{BC}}$ and $b_{\mathrm{abs}}$ are wavelength dependent. $\sigma_{\mathrm{abs}, \mathrm{BC}}$ depends on the type of aerosol, the aging and the size of the BC particles (Liousse et al., 1993) and thus needs to be determined for each site. The values used throughout this work 
Table 1. Summary of the different set of instrumentation for the different campaigns.

\begin{tabular}{|c|c|c|c|c|c|}
\hline \multirow[t]{2}{*}{ Instrument } & \multicolumn{4}{|c|}{ Sampling interval/averaging time } & \multirow[t]{2}{*}{ Continuously measured within GAW } \\
\hline & March 2004 & July-August 2004 & February-March 2005 & August 2005 & \\
\hline \multicolumn{6}{|l|}{ Mass concentration } \\
\hline PM1 betameter & $1 \mathrm{~min} / 24 \mathrm{~h}$ & $1 \mathrm{~min} / 24 \mathrm{~h}$ & $1 \mathrm{~min} / 48 \mathrm{~h}$ & $1 \mathrm{~min} / 48 \mathrm{~h}$ & Since 2004 \\
\hline PM1 mass derived from SMPS volume & $6 \mathrm{~min} / 24 \mathrm{~h}$ & $6 \mathrm{~min} / 24 \mathrm{~h}$ & $6 \mathrm{~min} / 48 \mathrm{~h}$ & & \\
\hline PM1 mass derived from Scattering coefficient & & & & $10 \mathrm{~min} / 48 \mathrm{~h}$ & Since 1995 \\
\hline TSP betameter & & $1 \mathrm{~min} / 24 \mathrm{~h}$ & $1 \mathrm{~min} / 48 \mathrm{~h}$ & $1 \mathrm{~min} / 48 \mathrm{~h}$ & $2004-2006^{1}$ \\
\hline TSP gravimetric filters & $48 \mathrm{~h}$ & $24 \mathrm{~h}$ & $24 \mathrm{~h} / 48 \mathrm{~h}$ & $24 \mathrm{~h} / 48 \mathrm{~h}$ & $1999-2005^{1}$ \\
\hline \multicolumn{6}{|l|}{ Chemical composition } \\
\hline PM1 filters & $24 \mathrm{~h}$ & $24 \mathrm{~h}$ & $48 \mathrm{~h}$ & $48 \mathrm{~h}$ & Since $1999^{2}$ \\
\hline TSP filters & $24 \mathrm{~h}$ & $24 \mathrm{~h}$ & $48 \mathrm{~h}$ & $48 \mathrm{~h}$ & Since $1999^{2}$ \\
\hline AMS & $1 \mathrm{~min} / 24 \mathrm{~h}$ & & $1 \mathrm{~min} / 48 \mathrm{~h}$ & & \\
\hline OC/EC Sunset analyzer & & & $6 \mathrm{~h} / 48 \mathrm{~h}$ & $6 \mathrm{~h} / 48 \mathrm{~h}$ & \\
\hline MAAP & $1 \mathrm{~min} / 24 \mathrm{~h}$ & $1 \mathrm{~min} / 24 \mathrm{~h}$ & $1 \mathrm{~min} / 48 \mathrm{~h}$ & $1 \mathrm{~min} / 48 \mathrm{~h}$ & Since 2003 \\
\hline
\end{tabular}

1 A PM10 cut was added to the TSP inlet in January 2007 for the TSP betameter and in January 2006 for the TSP gravimetric filters.

2 Aerosol particles are sampled on filters for $24 \mathrm{~h}$ every 6 th day.

are $7.4 \mathrm{~m}^{2} \mathrm{~g}^{-1}$ for the winter periods and $10.8 \mathrm{~m}^{2} \mathrm{~g}^{-1}$ for the summer at $630 \mathrm{~nm}$ and are detailed in Sect. 3.1.2. Measurements were performed with a time resolution of $1 \mathrm{~min}$. Comparison with another MAAP instrument running behind a PM2 inlet showed a very high correlation $\left(r^{2}=0.97\right)$ and a slope of 0.95 indicating that most of the BC mass is found below $d=2 \mu \mathrm{m}$ (Cozic et al., 2007).

Another light absorbing aerosol component is hematite $\left(\mathrm{Fe}_{2} \mathrm{O}_{3}\right)$, a minor component of mineral dust, which usually makes a small contribution but can be important during Saharan dust events (Collaud Coen et al., 2004). Because of the relatively low mass absorption efficiency of mineral dust $\left(\sigma_{\text {abs }}(660 \mathrm{~nm}) \sim 0.02-0.01 \mathrm{~m}^{2} \mathrm{~g}^{-1}\right)$ (Alfaro et al., 2004; Linke et al., 2006), the overall contribution of this component to the absorption coefficient is expected to be small during periods that are not influenced by Saharan dust events. Such Saharan dust episodes occur at the Jungfraujoch site on average 24 times a year (ranging from 10 to 34 per year in the last 5 years) with different duration (Collaud Coen et al., 2004). Light absorbing organic material is another component that is suspected to contribute to the measured absorption coefficient. Again, the low mass absorption efficiency associated with organic compounds (e.g. for humic like substances (HULIS) $\sigma_{\text {abs }}(532 \mathrm{~nm}) \sim 0.03 \mathrm{~m}^{2} \mathrm{~g}^{-1}$ (Hoffer et al., 2005)) would require unrealistically high concentrations of these compounds to significantly contribute to the measured absorption coefficient. We therefore assume that the measured absorption coefficient is entirely due to absorption by BC except during Saharan dust episodes.

\subsection{Semi-continuous OC/EC thermo-optical analyzer}

Organic carbon (OC) and elemental carbon (EC) in the total suspended particles (TSP) were measured using a semi-continuous OC/EC thermo-optical transmission analyzer (Sunset Laboratory) (Birch and Cary, 1996; Bae et al., 2004). Sampled particles are accumulated for 5 hours 45 minutes (flow rate $=7.5 \mathrm{~L} \mathrm{~min}^{-1}$ ) on a quartz filter housed within the instrument after the air has passed through a gas phase denuder (charcoal-impregnated filter strips, Sunset Laboratory) (Bae et al., 2004). After sampling, the filter is heated in an oxygen-free ultra high purity helium atmosphere in four increasing temperature steps, which permits the detection of various organic carbon fractions. During these heating steps some organic compounds may be pyrolytically converted to EC. This pyrolytic conversion is continuously monitored by measuring the transmission of a laser beam $(\lambda=660 \mathrm{~nm})$ through the filter. The organic compounds are vaporized and oxidized to carbon dioxide by a manganese dioxide catalyst held at a temperature of $800-900^{\circ} \mathrm{C}$. The gas is then switched to a $2 \% \mathrm{O}_{2} / \mathrm{He}$ mixture and the filter heated in two increasing temperature steps for determination of EC. In both cases, the evolved $\mathrm{CO}_{2}$ is measured using a continuous, non-dispersive infrared absorption (NDIR) method. At the end of each analysis an automatic internal calibration is performed by using a known volume and a fixed concentration of methane $\left(5 \% \mathrm{CH}_{4} ; 95 \% \mathrm{He}\right)$. A further, off-line calibration was conducted at the beginning and the end of each campaign with an external source of methane gas injected during the $\mathrm{He} / \mathrm{O}_{2}$ phase.

The determined EC includes both the original EC in the particles and that produced by the pyrolysis of organics. The point where the laser beam transmission through the sample returns to the original sample transmission defines the split between organic and elemental carbon (the instrument response prior to this point is assigned to $\mathrm{OC}$, and after this point is assigned to EC). This split point is determined 
automatically and is used to distinguish between EC and pyrolized OC. This discrimination is the major difficulty of the method: several temperature programs and results of intercomparison exercises are described in the literature (Chow et al., 2001; Schmid et al., 2001; Schauer et al., 2003). These studies generally show that the sensitivity of the separation between EC and OC using a TOT (thermal optical transmission) analysis method depends mainly on the temperature program and on the type of samples analyzed. Previous observations from the JFJ have shown that the split point was quite often in the last $\mathrm{OC}$ fraction and the pyrolized fraction was small.

The analyses were based on a temperature program provided by NIOSH (National Institute for Occupation Safety and Health). This consisted of a temperature increase to $840^{\circ} \mathrm{C}$ for the analysis of $\mathrm{OC}$ in $100 \% \mathrm{He}$ in a series of stages (1st step: $310^{\circ} \mathrm{C}$ for $60 \mathrm{~s}, 2 \mathrm{nd}$ step: $480^{\circ} \mathrm{C}$ for $60 \mathrm{~s}$, 3rd step: $615^{\circ} \mathrm{C}$ for $60 \mathrm{~s}$; 4 th step: $840^{\circ} \mathrm{C}$ for $90 \mathrm{~s}$ ), and up to $850^{\circ} \mathrm{C}$ for the analysis of $\mathrm{EC}$ in $98 \% \mathrm{He}+2 \% \mathrm{O}_{2}$ (1st step: $550^{\circ} \mathrm{C}$ for $35 \mathrm{~s}$; 2nd step: $850^{\circ} \mathrm{C}$ for $105 \mathrm{~s}$ ).

\subsection{Chemical composition of aerosol filter samples}

The filter sampling system was designed to sample two size fractions, total suspended particles (TSP) and particles with an aerodynamic diameter $d<1 \mu \mathrm{m}$ (PM1) (Henning et al., 2003). The two sizes fractions were selected according to the recommendations of the Global Atmosphere Watch (GAW) Scientific Advisory Group for Aerosol, reflecting the fact that the mass scattering efficiency is quite different for submicron and supermicron aerosols (Finlayson-Pitts and Pitts, 2000; GAW, 2007; IPCC, 2007). Four stages of a cascade impactor (Maenhaut et al., 1996) were used to generate the cut-off of $d=1 \mu \mathrm{m}$ with a flow rate of $11 \mathrm{~L} \mathrm{~min}^{-1}$. The flow was controlled by a mass flow controller (5851E Brooks Instrument, Fisher-Rosemount AG). The impactor stages were treated with high-vacuum grease to prevent bouncing. More details on the sampling system can be found in Henning et al. (2003)

Teflon filters (PTFE, Sartorius AG) with a pore size of $1.2 \mu \mathrm{m}$ and $47 \mathrm{~mm}$ diameter were used to sample the aerosol particles, and Nylon filters (Nyabsorb, PALL/Gelman Sciences), with a pore size of $1 \mu \mathrm{m}$, were used for the collection of nitrate evaporating from the first filter (Zhang and McMurry, 1992; Cheng and Tsai, 1997). As explained by Henning et al. (2003), gaseous nitric acid was lost to the walls of the inlet system ( $4.5 \mathrm{~m}$ length, $11 \mathrm{~s}$ residence time) during sampling and so any nitrate measured on the backup Nylon filter was assumed to originate from ammonium nitrate. In the following, $\mathrm{NO}_{3}^{-}$data are presented as the sum of nitrate from the Teflon and the Nylon filters in order to obtain the total aerosol nitrate. For $\mathrm{NH}_{4}^{+}$, the total ammonium concentration was obtained by the addition of the ammonium determined on the Teflon filter plus an equivalent amount of am- monium estimated from the associated nitrate on the backup filter.

It was found that cleaning of the filters with deionized water, $\mathrm{NaOH}$ or methanol was unnecessary because of the low blank values of the filters. This assumption was tested regularly. All filters were stored in Petri dishes lined with baked aluminum foil liners and placed in sealed polyethylene bags. All filters were stored at $-18^{\circ} \mathrm{C}$ until their analysis.

The samples were analyzed for water soluble ionic components with ion chromatography in a clean room after aqueous extraction of the filters in SCHOTT bottles. For the Teflon filters this was done using $0.3 \mathrm{~mL}$ of methanol (Baker CMOS grade) in order to first wet the Teflon filters, followed with $8.7 \mathrm{~mL}$ of deionized (DI) water, while for the Nylon filters the extraction was performed with $5 \mathrm{~mL}$ of DI water. Extracts were analyzed within 1 hour after extraction in order to limit possible oxidation reactions in the liquid phase. The cations $\left(\mathrm{Na}^{+}, \mathrm{NH}_{4}^{+}, \mathrm{K}^{+}, \mathrm{Ca}^{2+}\right)$ were analyzed with a DIONEX DX320 chromatograph using a CS16 column 4 $\mathrm{mm}$ with a CG16 guard column, and chemical regeneration was performed with a CSRS ULTRA II autosuppressor. The injection loop volume was $0.6 \mathrm{~mL}$. The analyses were performed under isocratic MSA conditions, at $40 \mathrm{mM}$ and with a flow rate of $1.5 \mathrm{~mL} \mathrm{~min}^{-1}$. Analysis of the anions was performed in parallel with a DIONEX ICS 2500 chromatograph using an AS11 column (4 mm) with an AG11 guard column and an ASRS ULTRA II autosuppressor at a flow rate of $1.5 \mathrm{~mL} \mathrm{~min}^{-1}$. Injections were made via a $1-\mathrm{mL}$ injection loop. The eluent $(\mathrm{KOH})$ was generated with an EG50 eluent generator. Gradient conditions were adapted from Ricard et al. (2002) but no methanol was used in the composition of eluents. The 15-min runs allowed for the detection of the major inorganic anions $\left(\mathrm{Cl}^{-}, \mathrm{NO}_{3}^{-}, \mathrm{SO}_{4}^{2-}\right)$ and of oxalic acid.

Blank levels for each chemical species were calculated from the analysis of 30 procedural blanks and were subtracted from the measured sample concentrations to obtain the actual concentrations. Atmospheric detection limits were calculated as twice the standard deviation of the blank sample concentrations, using a typical sampling duration of $24 \mathrm{~h}$. Major components (sulfate, chloride, sodium, ammonium, nitrate, potassium, and calcium) were almost always above detection limit $\left(\mathrm{SO}_{4}^{2-}(8.5), \mathrm{Cl}^{-}(5.4), \mathrm{Na}^{+}\right.$(9.3), $\mathrm{NH}_{4}^{+}$(2.8), $\mathrm{NO}_{3}^{-}$(17.6), $\mathrm{K}^{+}$(3.0) and $\mathrm{Ca}^{2+}(10.7)$ in $\mathrm{ng} \mathrm{m}^{-3}$ ). The chemical composition of the coarse mode particles was calculated by the difference between the TSP and PM1 data.

\subsection{Aerosol Mass Spectrometer}

An Aerodyne Quadrupole Aerosol Mass Spectrometer (QAMS, Jayne et al. (2000)) was used for measuring on-line chemically resolved mass concentrations and size distributions of non-refractory aerosol components (sulfate, nitrate, ammonium, organics), in a vacuum aerodynamic diameter range $d_{v a}=50-700 \mathrm{~nm}$. In the Q-AMS, the particles are drawn into vacuum through an aerodynamic lens sampling 
inlet system (Zhang et al., 2002), which focuses aerosol particles into a narrow, collimated beam that impacts on a porous tungsten surface (the vaporizer) heated typically to $500^{\circ} \mathrm{C}$ under high vacuum $\left(\sim 10^{-8}\right.$ torr). The non-refractory fraction of the particles, mostly the volatile and semi-volatile components, flash vaporizes upon contact with the vaporizer surface on a time scale of a few microseconds. The resultant gaseous molecular constituents are ionized using a 70$\mathrm{eV}$ electron impact ionization source positioned such that the maximum electron density and the centre of the vaporized plume are co-located in the extraction zone of the mass spectrometer. A quadrupole mass spectrometer (QMA 410, Balzers Instruments, Balzers) is utilized to analyze the positive ions with unit mass-to-charge $(\mathrm{m} / \mathrm{z})$ resolution. For more details see Allan et al. (2003).

\subsection{Particle size distribution measurements}

A scanning mobility particle sizer (SMPS, TSI 3934), comprising a differential mobility analyzer (DMA, TSI 3071) and condensation particle counter (CPC, TSI 3022), was used to measure the particle size distribution between 17 and $900 \mathrm{~nm}$ (dry) diameter (Verheggen et al., 2007). The SMPS had a closed loop configuration for the sheath and excess air, which was held constant at $3 \mathrm{~L} \mathrm{~min}^{-1}$ by a critical orifice, while the sample flow rate was $0.3 \mathrm{~L} \mathrm{~min}^{-1}$. A correction was applied to the measured diameters to account for the reduced pressure at the Jungfraujoch (650 mbar on average). Latex spheres, nebulized into the SMPS were used to confirm that the instrument was correctly sizing. The SMPS was frequently compared to another SMPS and systematic differences in integrated concentrations $<5 \%$ were encountered. Aerosol volume concentrations with $d<900 \mathrm{~nm}$ were derived from the measured SMPS number size distributions, assuming that the particles were spherical.

Additionally, an optical particle counter (OPC, Grimm Dustmonitor 1.108) was operated to measure the particle size distribution in the optical diameter range $d=0.3-20 \mu \mathrm{m}$. The comparison of the size distribution spectra of the GRIMM and the SMPS showed a very good agreement for FebruaryMarch 2005 whereas for March 2004 the OPC diameters would need to be slightly shifted (multiplied by 1.2) to larger sizes to get a good agreement. The slight discontinuity in the combined number size distribution is likely to result from the fact that in the OPC the individual particles are classified according to their light scattering behavior, which depends on the particle size, morphology and refractive index. Since the OPC is calibrated with spherical Latex particles the observed shift is most probably due to the different refractive index (and complex morphology) of the measured particles in the range $d=300-1000 \mathrm{~nm}$.

\subsection{Betameter TSP and PM1}

A beta-attenuation monitor (Thermo ESM Andersen FH62 IR) was used for continuous measurements of TSP and PM1 mass concentration (Baltensperger et al., 2001). A glass fiber filter collects sampled particles whilst being exposed to a continuous flux of beta particles. The beta particles are emitted with a continuum energy distribution by a radioisotope source and are attenuated by a reference section and the sample. The transmitted fraction of the beta particles is measured using an electron counter. The number of beta particles transmitted through the sample decreases exponentially as the thickness of the deposited material increases according to Evans (1955),

$I=I_{0} \cdot e^{-\mu \cdot x}$

where $I_{0}$ is the incident flux, $\mu$ is the mass absorption coefficient for $\beta$ radiation absorption $\left(\mathrm{cm}^{2} \mathrm{~g}^{-1}\right)$, and $x$ is the mass thickness of the sample $\left(\mathrm{g} \mathrm{cm}^{-2}\right)$. The mass absorption coefficient is determined through a calibration procedure involving the measurement of a series of known standards (calibration foils), which bracket the mass range of interest (Jaklevic and Gatti, 1981).

\subsection{High-volume sampler for TSP}

A high-volume sampler (HIVOL DHA80, Digitel, Hegnau) was used to determine 48 -h averages of total suspended mass concentrations. TSP was collected for 2 days on glass fiber filters (Ederol 227/1/60, diameter $15 \mathrm{~cm}$, Digitel) with a flow rate of $45 \mathrm{~m}^{3} \mathrm{~h}^{-1}$. The mass concentrations were determined gravimetrically by weighing the filters before and after sampling (Mettler, AE200). From January 2006 onwards, the sampling intervals were reduced to $24 \mathrm{~h}$ and the glass fiber filters were replaced by quartz fiber filters (QMA20, Whatman, Dassel).

\subsection{Nephelometer}

The aerosol light scattering coefficients of TSP were simultaneously measured at three wavelengths $(\lambda=450,550$, and $700 \mathrm{~nm}$ ) by an Integrating Nephelometer (IN, TSI 3563). The sampled aerosol is illuminated over an angle of 7 to $170^{\circ}$ by a halogen light source directed through an optical pipe and an opal glass diffuser. The sample volume is viewed by three photomultiplier tubes through a series of apertures set along the axis of the main instrument body. Aerosol scattering is viewed against the dark backdrop of a very efficient light trap. 

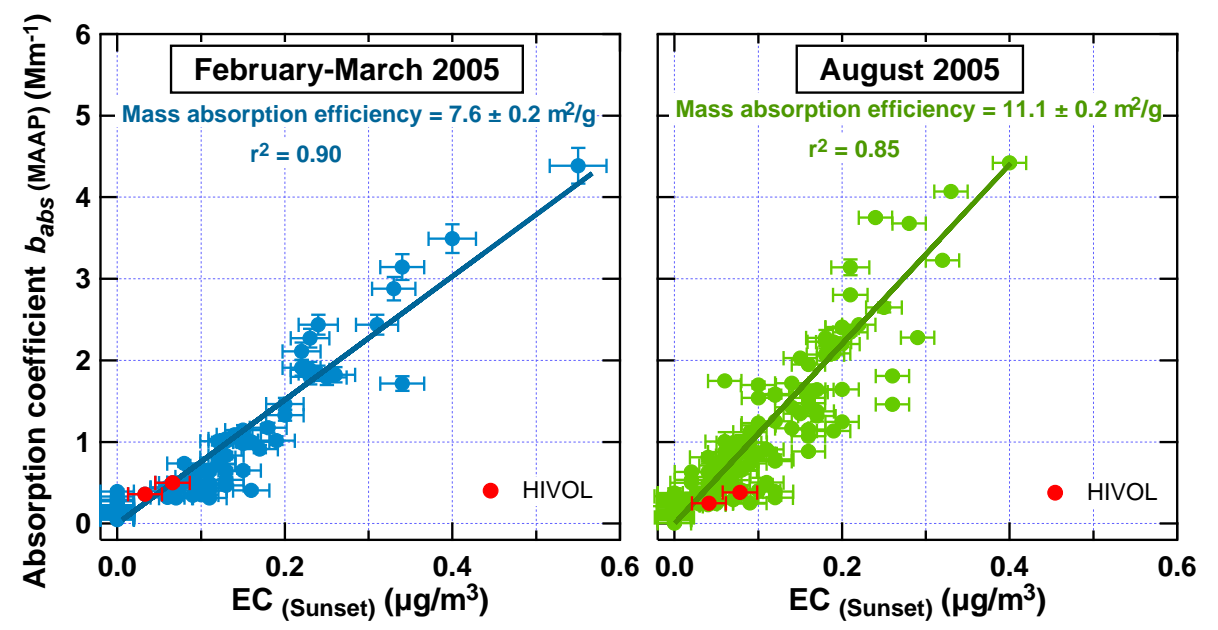

Fig. 1. Comparison of the absorption coefficient from the MAAP with the EC concentration determined by the OC/EC analyzer in FebruaryMarch 2005 (a) and August 2005 (b) with $6 \mathrm{~h}$ averaging time. The slope represents the mass absorption efficiency.

\section{Results}

\subsection{Measurement validation}

\subsubsection{Mass absorption efficiency}

The mass absorption efficiency $\sigma_{\mathrm{abs}, \mathrm{BC}}$ of the Jungfraujoch aerosol was determined from the EC measurements of the OC/EC analyzer and the light absorption measurements (MAAP). $\sigma_{\mathrm{abs}, \mathrm{BC}}$ is wavelength dependent and is determined at $\lambda=630 \mathrm{~nm}$. A large range of values $\left(2-25 \mathrm{~m}^{2} \mathrm{~g}^{-1}\right)$ has been reported in the literature (Bond and Bergstrom (2006) and references therein). This variability is partly caused by differences in the aerosol mixing state, with external mixtures favoring smaller values, while larger values indicate internal mixing of BC (Liousse et al., 1993). Consequently, $\sigma_{\mathrm{abs}, \mathrm{BC}}$ depends on the aerosol composition, mixing state and to a lesser extent on particle size. However, it is believed that a major contribution to this wide range is caused by the variability in the different methods to determine EC and BC (Schmid et al., 2001).

Figure 1 shows the comparison between the absorption coefficient $b_{\text {abs }}$ measured by the MAAP with the EC concentration determined by the OC/EC analyzer in February-March 2005 and in August 2005. A reduced major axis regression was performed on the data to account for the error of each instrument (Ayers, 2001). Noise was introduced into the data to estimate the error on the mass absorption efficiency. The mass absorption efficiency is higher in summer $\left(11.1 \pm 0.2 \mathrm{~m}^{2} \mathrm{~g}^{-1}\right)$ compared to winter $\left(7.6 \pm 0.2 \mathrm{~m}^{2} \mathrm{~g}^{-1}\right)$. The reasons for this difference are currently unclear but could be due to a greater coating of $\mathrm{BC}$ particles by e.g. organic compounds due to increased photochemical activity during summer. Such coatings may lead to increases in the mass absorption efficiency (Fuller et al., 1999). This seasonality in the mass absorption efficiency has been seen in other studies such as Sharma et al. (2002) in the Canadian Arctic, but not in a previous study at the Jungfraujoch (Lavanchy et al., 1999). The latter may be due to the fact that different procedures were applied in the different campaigns: Lavanchy et al. (1999) used a 2-step thermal method which did not correct for potential pyrolysis and the Aethalometer data were not corrected for scattering effects.

\subsubsection{Q-AMS collection efficiency}

It is known that the collection efficiencies of ambient aerosol particles are often less than $100 \%$ within the aerosol mass spectrometer, and so the Q-AMS data have to be corrected for this. This requirement arises because particles containing large fractions of slightly less-volatile mass (such as solid ammonium sulfate) can sometimes bounce off the Q-AMS heater before they evaporate, and so the "missing mass" of these particles is not measured. The collection efficiency compensates for this missing mass, and is usually derived by comparing the data for the non-refractory aerosol components (such as $\mathrm{SO}_{4}^{2-}$ ) with simultaneously collected filter data (in this case the PM1 filter data).

Figure 2 shows the comparison of the $\mathrm{SO}_{4}^{2-}$ concentrations measured with the Q-AMS and on the filters. The slope of the linear correlation yields the Q-AMS collection efficiency. A collection efficiency of 0.48 was determined for sulfate. Since the aerosol in the fine mode has been shown to be mainly internally mixed at Jungfraujoch (Weingartner et al., 2002; Cozic et al., 2007), the collection efficiency of 0.48 was applied to all compounds $\left(\mathrm{SO}_{4}^{2-}, \mathrm{NO}_{3}^{-}, \mathrm{NH}_{4}^{+}\right.$, organics) measured by the Q-AMS. The coefficient is consistent with values found in previous studies (Canagaratna et al., 2007 and references therein). 


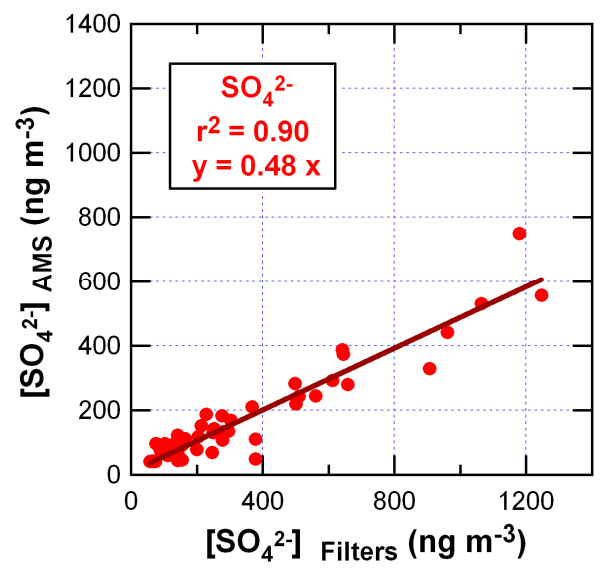

Fig. 2. Comparison of the $\mathrm{SO}_{4}^{2-}$ (PM1) concentrations measured with Q-AMS and on filters over 24-h averaging intervals in March 2004.

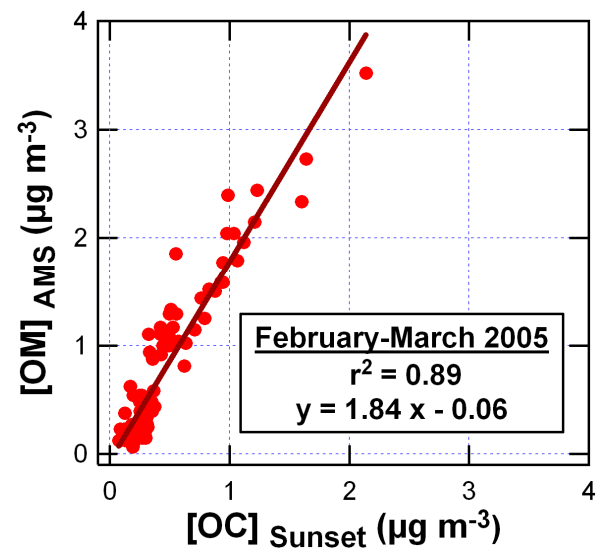

Fig. 3. Comparison of the organic mass from the Q-AMS (OM) with the organic carbon concentration from the OC/EC analyzer (OC) for February-March 2005, with an averaging time of $6 \mathrm{~h}$.

\subsubsection{Organic Matter (OM) and Organic Carbon (OC)}

The OC/EC analyzer measures organic carbon (OC) and does not consider the other atoms associated with organic matter, such as $\mathrm{O}, \mathrm{H}, \mathrm{N}$ and $\mathrm{S}$. In contrast, the organic mass concentration from the Q-AMS represents the total organic matter $(\mathrm{OM})$ associated with all atoms present. The comparison between these two measurements yields information on the conversion factor of OC to OM for the Jungfraujoch aerosol. This comparison was only possible in February-March 2005 when the Q-AMS and the Sunset analyzer were sampling simultaneously. An offset correction was applied to the OC concentration data obtained from the Sunset analyzer, as a detailed analysis revealed an offset in the Sunset data of about $0.3 \mu \mathrm{g} \mathrm{m}^{-3}$. Laboratory tests were performed to determine the source of this offset. All tests were conducted in nitrogen gas (quality 5.0), which was further purified with

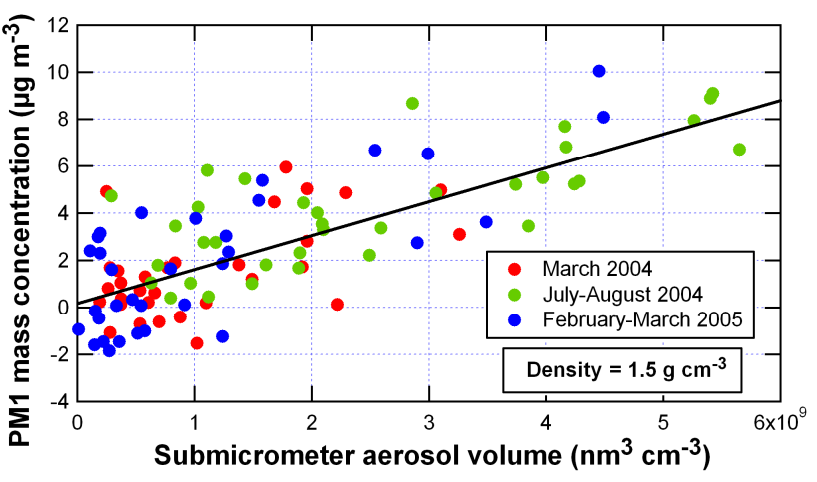

Fig. 4. Comparison of the PM1 mass concentration (betameter) with the aerosol volume concentration derived from the SMPS for winter and summer (24-h averaging time). The slope yields the effective density.

a pure air generator (AADCO Instruments Inc., 737-250 series). According to the manufacturer's specifications impurities were $<1 \mathrm{ppb}$ each for ozone, methane and non-methane hydrocarbons, oxides of nitrogen $\left(\mathrm{NO} / \mathrm{NO}_{\mathrm{x}}\right)$, hydrogen sulfide $\left(\mathrm{H}_{2} \mathrm{~S}\right)$, sulfur dioxide $\left(\mathrm{SO}_{2}\right)$, carbonyl sulfide $(\mathrm{COS})$, carbon monoxide $(\mathrm{CO})$, sulfur hexafluoride $\left(\mathrm{SF}_{6}\right)$, and fluorocarbons. In addition, a particle filter and a denuder were installed in front of the instrument inlet to remove particles and semi volatile gases from the air. The source of this offset could not be determined. It did not increase with sampling time (up to $24 \mathrm{~h}$ ) and was only present in the first two steps of the OC temperature program. A leak or penetration of compounds through the denuder would have resulted in a blank that increased with sampling time. These offsets were estimated to 0.2 and $0.1 \mu \mathrm{g}$ for the $1 \mathrm{st}$ and 2 nd peaks, respectively, and were subtracted from the respective peaks measured in the field.

As can be seen in Fig. 3 there is a high correlation between the OC and the OM $\left(r^{2}=0.89\right)$ and the conversion factor of $\mathrm{OC}$ to $\mathrm{OM}$ is 1.84 . This finding is in agreement with literature data where values between 1.6 to 2.1 have been reported (Turpin and Lim, 2001). An even higher OM:OC ratio might be expected for the Jungfraujoch aerosol due to its remote location. This coefficient could be slightly decreased by the size cut of $1 \mu \mathrm{m}$ used for the Q-AMS whereas the OC/EC analyzer was running with TSP. However, it is not expected that this will have a strong influence at the JFJ as, like sulfate, the major fraction of OC is found in the fine mode. The same coefficient is used in this analysis for winter and summer data since no Q-AMS was running during the summer period. In summer this coefficient is expected to be higher due to the larger biogenic emissions and increased photochemical activity. 

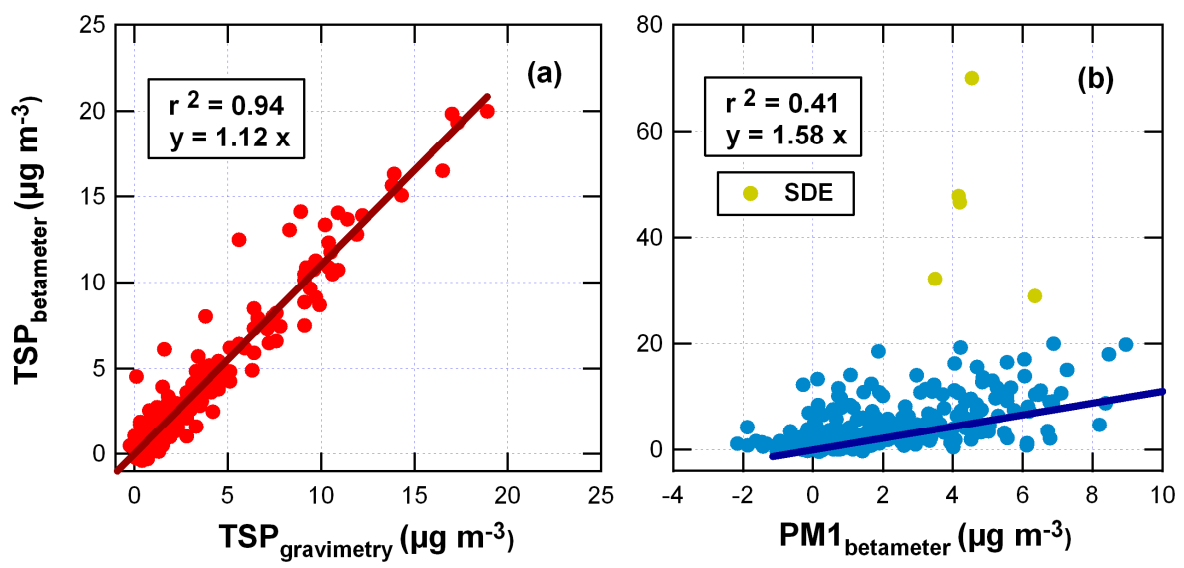

Fig. 5. Comparison of the TSP mass determined with a betameter and by gravimetry for January 2004 to January 2006 (a) and the TSP and PM1 mass measured with betameters for February 2004 to January 2007 (b) for 48-h averaging intervals.

\subsubsection{Betameter PM1 and SMPS mass concentration}

The PM1 data from the betameter have very low signal to noise ratios and so long periods are used to average the data (typically 1 day). A higher temporal resolution of PM1 can be obtained by correlating the PM1 data (24-h averages) with the volume concentrations obtained from the measured SMPS size spectra $(d=17-900 \mathrm{~nm})$ and estimating an aerosol density. Although there are a large number of particles with $d<17 \mathrm{~nm}$, these small particles can be neglected when calculating the submicrometer aerosol volume concentration (Imhof et al., 2005). The missing aerosol volume between 900 and $1000 \mathrm{~nm}$ can also be considered as negligible when strong episodes of mineral dust are absent, as shown in the size distributions below (Sect. 3.4).

Figure 4 shows the comparison of the PM1 mass concentration with the submicrometer aerosol volume for March 2004, February-March 2005, and August 2004 (24 h averaging time). The correlation is rather weak $\left(r^{2}=0.53\right)$ as a result of the low signal to noise ratio of the betameter measurements. The conversion factor corresponds to an effective particle density of $1.5 \mathrm{~g} \mathrm{~cm}^{-3}$ which is consistent with the values observed at Monte Cimone (Putaud et al., 2004b), Hyytiälä (Virtanen et al., 2006) and those summarized by McMurry et al. (2002). Thus we conclude that it is appropriate to estimate the PM1 mass concentration from the SMPS volume concentration when SMPS measurements were available (winter campaigns) by using an effective particle density of $1.5 \mathrm{~g} \mathrm{~cm}^{-3}$. In summer, the concentrations were higher, resulting in higher signal to noise ratios in the betameter data.

\subsubsection{Betameter TSP and Gravimetric TSP}

The correlation between the two TSP measurements (Fig. 5a) is high $\left(r^{2}=0.94\right)$, with a slope slightly higher than unity $\left(\mathrm{TSP}_{\text {betameter }}=1.12 \times \mathrm{TSP}_{\text {gravimetric }}\right)$. The slightly high slope could be due to the calibration of the betameter at the
Jungfraujoch. The comparison between the betameter data for TSP and PM1 (Fig. 5b) reveals that the signal of the PM1 betameter is much lower than TSP betameter as expected $\left(\mathrm{TSP}_{\text {betameter }}=1.58 \times \mathrm{PM} 1_{\text {betameter }}\right)$, but is also noisier and yields a lower correlation $\left(r^{2}=0.41\right)$. Episodes of Saharan dust (yellow points in Fig. 5b determined by the method described by Collaud Coen et al. (2004)) were excluded from the correlation, since they show much higher concentrations of coarse mode particles.

\subsection{Long-term chemical composition}

Since June 1999 inorganic compounds in PM1 and TSP have been determined on a semi-continuous basis ( $24 \mathrm{~h}$ sampling every 6th day) on the JFJ within the GAW aerosol program and are available at http://www.nilu.no/projects/ccc/create/ database.htm. Long-term ionic measurements at various European sites were published by Putaud et al. (2004a). However, only annual averages were presented for fewer components. Malm et al. (2004) presented a summary of monthly data for different sites within the US. They showed temporal variations over a year but no year to year variation was discussed. Long-term series are available for individual components such as sulfate (e.g., Malm et al., 2002). This paper is to our knowledge the longest time series of inorganic aerosol composition at a high altitude site presented so far. In addition the mass concentrations of PM1 and TSP have been measured since February 2004 and June 1999 respectively. Figure 6 presents the long-term measurements of the major PM1 and TSP compounds detected $\left(\mathrm{SO}_{4}^{2-}, \mathrm{NH}_{4}^{+}, \mathrm{NO}_{3}^{-}\right.$, $\mathrm{Ca}^{2+}, \mathrm{K}^{+}, \mathrm{C}_{2} \mathrm{O}_{4}^{2-}, \mathrm{Cl}^{-}, \mathrm{Na}^{+}$), as well as the TSP mass concentration determined by gravimetry and the PM1 mass determined with a betameter (since January 2004 only).

For all compounds a clear seasonality is observed with low concentrations in winter when the aerosol is typical of the undisturbed free troposphere, and maximum concentrations 


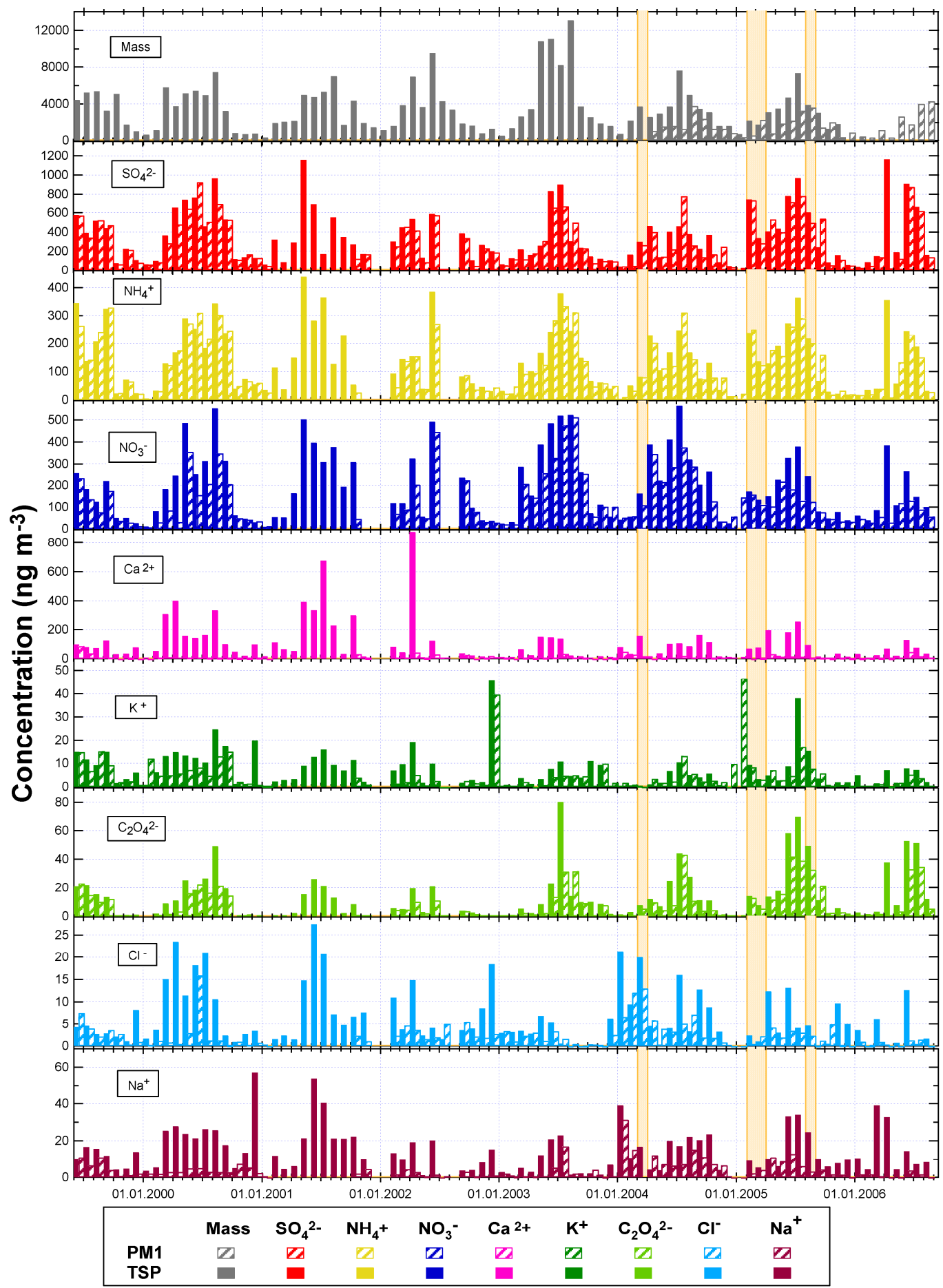

Fig. 6. Temporal evolutions of monthly averaged mass (TSP (gravimetry); PM1 (betameter) and chemical component concentrations (filters) for the period June 1999 to September 2006. Orange bands represent the time periods when further information on chemical composition was measured during intensive field campaigns.

in summer when the Jungfraujoch is influenced by injections from the planetary boundary layer (PBL). First evidence on the importance of vertical transport for the Jungfraujoch aerosol was published by Baltensperger et al. (1991). De- tailed analyses on the influence of the PBL were presented by Lugauer et al. $(2000,1998)$ showing that vertical aerosol transport by thermally driven convection, acting between late spring and late summer, is the dominant transport process at 


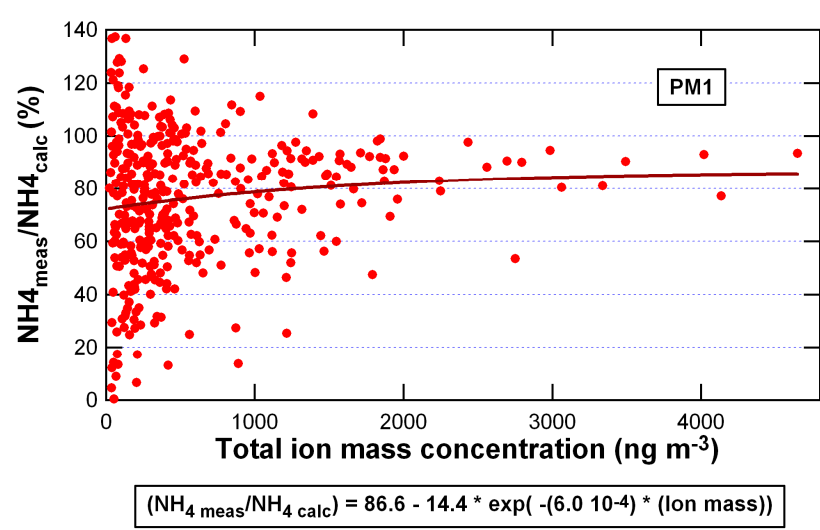

Fig. 7. Ratio of the measured $\mathrm{NH}_{4}$ mass to the $\mathrm{NH}_{4}$ calculated to reach neutralization (i.e. formation of $\left.\left(\mathrm{NH}_{4} \mathrm{NO}_{3} ;\left(\mathrm{NH}_{4}\right)_{2} \mathrm{SO}_{4}\right)\right)$ as a function of the total ion mass concentration for PM1 measured with filters (daily averages). The exponential fitted line is also presented.

the Jungfraujoch. This was also shown for individual chemical components (Zellweger et al., 2000). Gehrig and Buchmann (2003) presented an overview of seasonal variations of aerosol concentrations at various sites in Switzerland and showed that the PM concentrations are higher in winter than in summer due to reduced vertical transport. For $\mathrm{SO}_{2}$, this reduced dilution along with enhanced emissions during winter results in higher concentrations in winter than in summer (Hueglin et al., 2005; Fisseha et al., 2006). Conversely, in summer the photochemical oxidation rates are enhanced. Therefore, the resulting $\mathrm{SO}_{4}^{2-}$ is relatively constant over the year in the valleys (Hueglin et al., 2005). Thus, the higher concentrations at the Jungfraujoch in summer are mainly due to enhanced vertical transport. Such seasonal behavior was also observed by Fischer et al. (2007) at Mount Washington. In contrast, for Alert, a remote site in the Arctic, Sirois and Barrie (1999) showed an opposite seasonal cycle with higher concentrations in winter than in summer, driven by a strong seasonality in south to north transport and in wet and dry removal.

In Fig. 6 it can be seen that highest TSP mass concentrations were reached in summer 2003 when Europe encountered exceptionally high temperatures which led to increased convection in the Alps and thus enhanced injection of PBL air. These high signals in summer 2003 were also observed in other continuous aerosol measured parameters such as the light scattering coefficients (Collaud Coen et al., 2007). However, of the chemical components measured, only $\mathrm{NO}_{3}^{-}$ showed a significant enhancement.

No statistically significant trends in the major ionic species could be obtained from this data set in contrast to other aerosol parameters measured within the GAW program for which clear trends were observed (Collaud Coen et al., 2007). This might be explained by a lower temporal coverage of the chemical composition samples $(24 \mathrm{~h}$ sampling

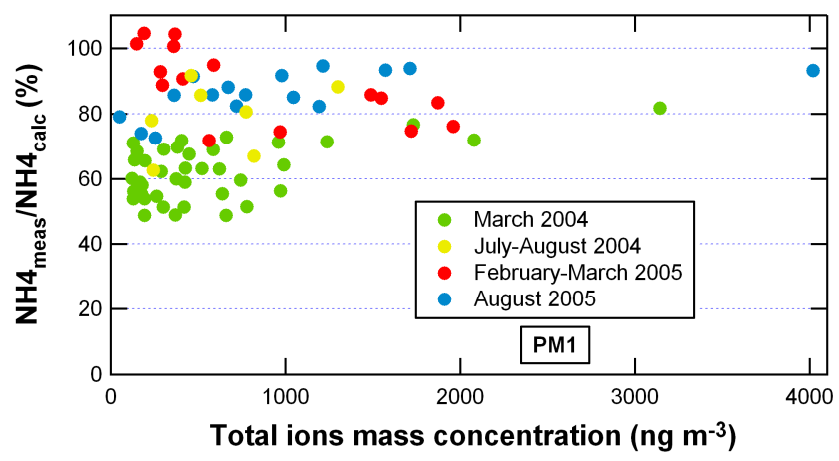

Fig. 8. Ratio of the $\mathrm{NH}_{4}$ mass to the $\mathrm{NH}_{4}$ calculated to reach neutralization (i.e. formation of $\left.\left(\mathrm{NH}_{4} \mathrm{NO}_{3} ;\left(\mathrm{NH}_{4}\right)_{2} \mathrm{SO}_{4}\right)\right)$ as a function of the total ion mass concentration for PM1 during the intensive campaigns (daily averages).

every 6 days instead of continuously as for the other parameters) and/or by a higher year to year variation. Both possibilities lead one to conclude that there is a need for a longer time series to detect statistically significant trends. In addition, a decrease with time was observed for the TSP mass concentration for the period 1975 to 2005 , however, this trend was not significant for the last 9 years (Christoph Hüglin, personal communication). Husain et al. (2004) presented longterm trends of sulfate from 1984 to 2003 at a site comparable to the Jungfraujoch (Whiteface Mountain) and showed a decreasing trend in sulfate concentrations. Nevertheless, they also indicated that this trend was less pronounced since 1995 .

The different intensive campaigns are marked as orange bands in Fig. 6. There are clear differences between the two winter campaigns. During the period February-March 2005, unusually high concentrations were observed for a winter period (e.g. $\sim 700 \mathrm{ng} \mathrm{m}^{-3}$ for $\mathrm{SO}_{4}^{2-}$ instead of $<400 \mathrm{ng} \mathrm{m}^{-3}$ for winter in other years) and concentrations similar to those found in summer were measured. The campaign in August 2005 was performed after the maximum PBL influence at the JFJ in that year, and the month of August 2005 was cool and cloudy which resulted in low influence from the PBL.

\subsection{Aerosol neutralization}

The degree of neutralization of the aerosol (PM1 only) is presented in Fig. 7, which shows the ratio of the measured $\mathrm{NH}_{4}^{+}$ to the amount of $\mathrm{NH}_{4}^{+}$that is needed to neutralize nitric and sulfuric acid as a function of the total ion mass concentration. The entire 6-year data set is shown in the figure, each data point representing a single $24-\mathrm{h}$ sample. The Jungfraujoch aerosol is, to within the noise in the data, neutralized, since the average ratio is about $80 \%$. At low mass concentrations there is a slight tendency for an increased acidity, but there is considerable scatter at these low concentrations. This tendency might be due to the fact that ammonia has a very strong gradient with altitude (Beig and Brasseur, 2000); 

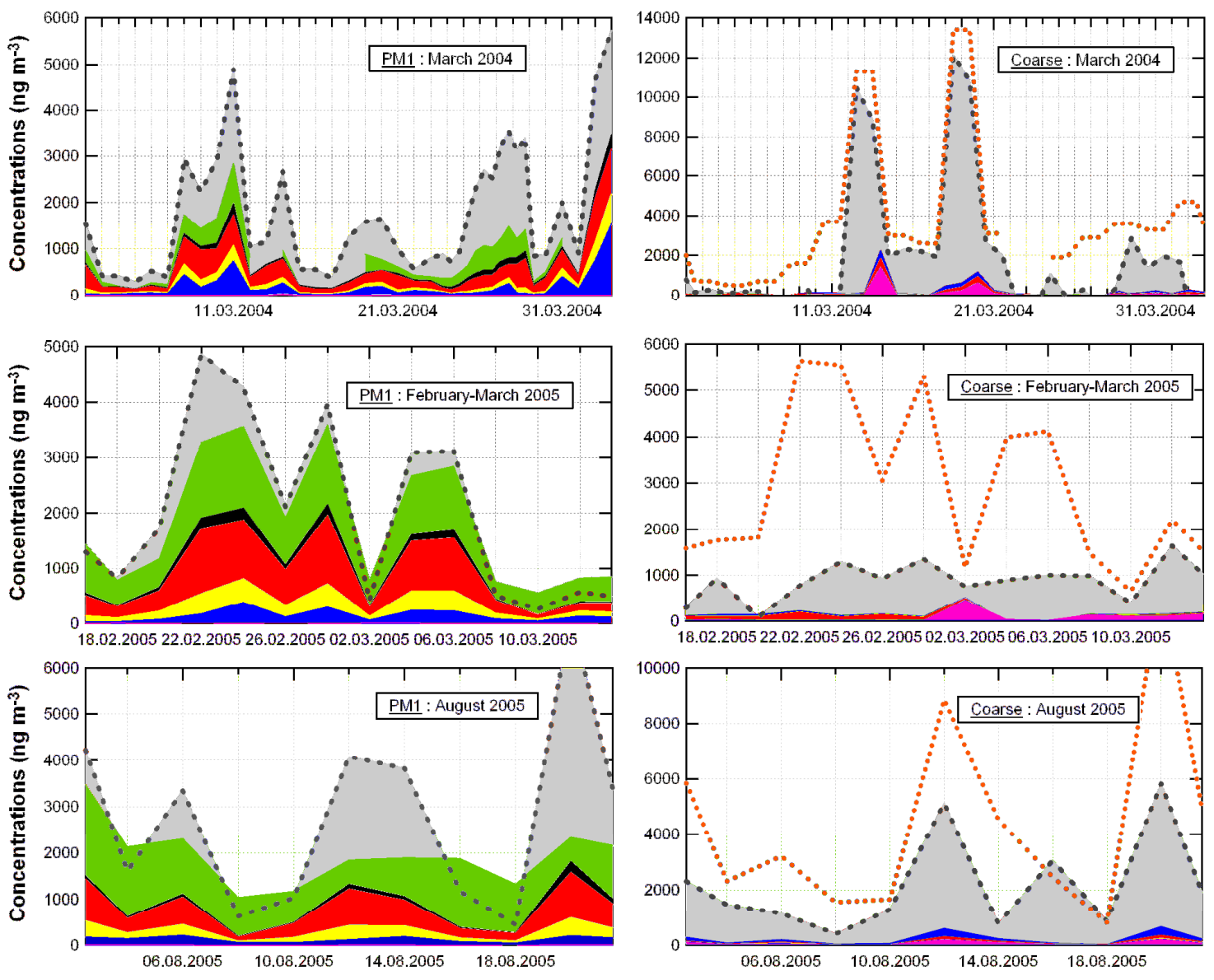

$\mathrm{NO} 3 \quad \mathrm{NH} 4 \square \mathrm{SO} 4 \square \mathrm{OM}$

PM1 (left) or Coarse mass (right)

-... $\mathrm{BC}$ TSP mass

Fig. 9. Time series of the chemical composition of PM1 (left) and the coarse mode (right) for March 2004, February-March 2005, and August 2005. The inorganic composition was determined from filters, BC was measured with a MAAP and OM fraction was measured with an OC/EC analyzer (except for March 2004 where OM data are from a Q-AMS). PM1 mass concentration was derived from SMPS (except for August 2005 where it was deduced from the aerosol scattering coefficient at $450 \mathrm{~nm}$ ). TSP mass concentration was measured with a betameter (except for March 2004 where data are from gravimetric measurement).

thus a high degree of acidity may indicate an influence of free tropospheric air.

During the intensive field campaigns in March 2004, the aerosol was found to be substantially more acidic than in February-March 2005 and August 2005 (Fig. 8). As explained above, this might indicate an influence of free tropospheric air. There are more rigorous methods to determine aerosol acidity (Keene et al., 2004), but the necessary measurements were not made during these campaigns.

\subsection{Chemical mass balance for PM1 and the coarse mode}

Time series of the chemical mass balance for PM1 and coarse mode for three intensive field campaigns in March 2004, February-March 2005 and August 2005 are presented in Fig. 9. No mass closure is given for July-August 2004 since the organic mass concentration was not measured during this period.

Figure 9 presents the various measured chemical fractions as well as total PM1, total coarse and TSP mass concentrations. As explained in Sect. 3.1.4, the PM1 mass concentration was derived from the SMPS volume concentration for March 2004 and February-March 2005. No SMPS data were available for the August 2005 experiment. For this campaign, the aerosol light scattering coefficient at wavelength $\lambda=450 \mathrm{~nm}$ was used as a proxy for the PM1 mass concentration. The SMPS derived volume concentrations were compared to the measured aerosol light scattering coefficients at $450 \mathrm{~nm}$. The analysis showed a high correlation $\left(r^{2}=0.71\right.$, slope $=5.95 \times 10^{-6} \mathrm{~m}^{-1} \mathrm{~cm}^{3} \mu \mathrm{m}^{-3}$ (March 2004); $r^{2}=0.98$, slope $=6.14 \times 10^{-6} \mathrm{~m}^{-1} \mathrm{~cm}^{3} \mu \mathrm{m}^{-3}$ (JulyAugust 2004); $r^{2}=0.94$, slope $=6.92 \times 10^{-6} \mathrm{~m}^{-1} \mathrm{~cm}^{3} \mu \mathrm{m}^{-3}$ 

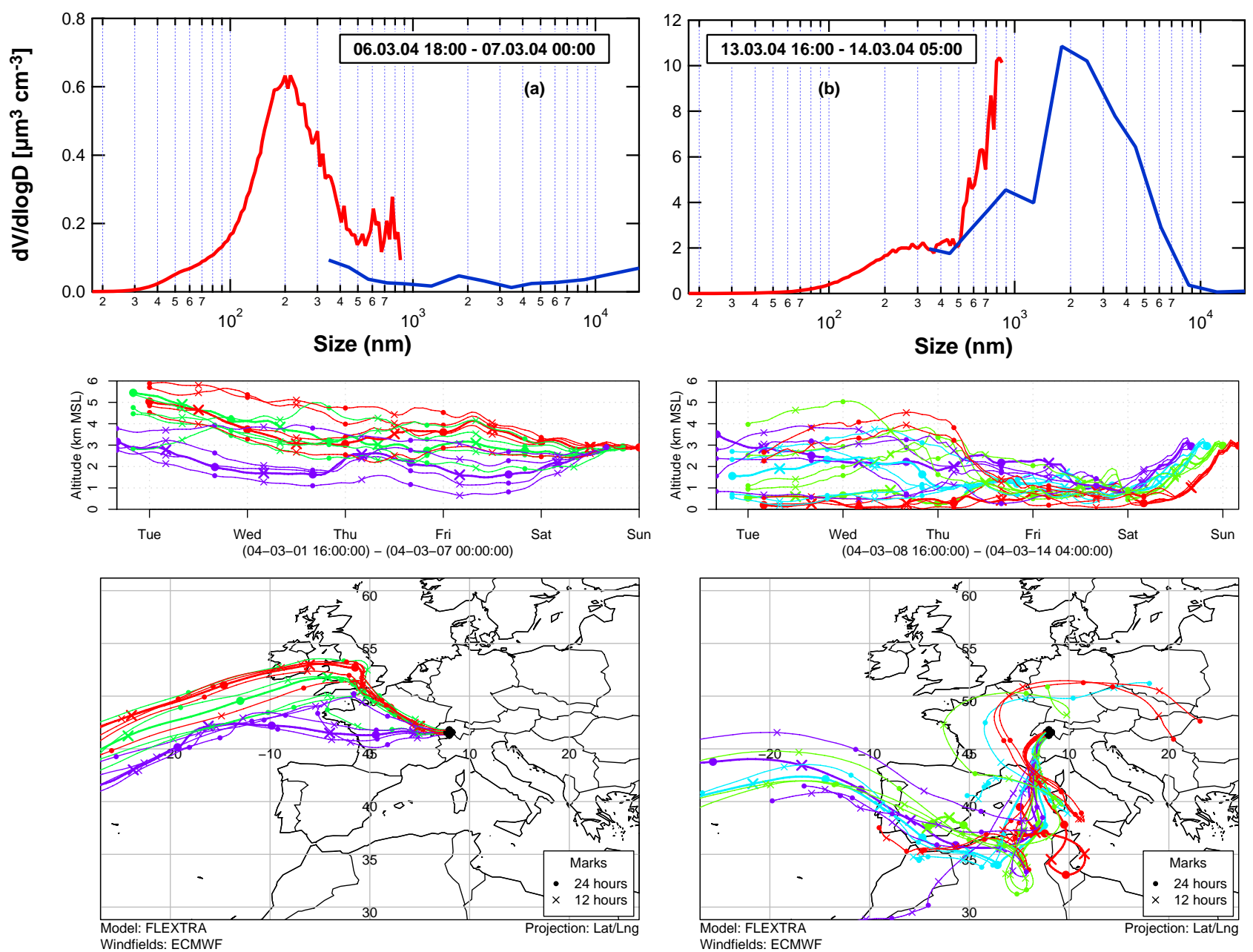

Fig. 10. Top: Size distributions measured with an SMPS for diameters below $800 \mathrm{~nm}$ and with an OPC for diameters above $300 \mathrm{~nm}$. Bottom: back-trajectories calculated with the FLEXTRA model for two periods without (a) and with (b) influence of mineral dust.

(February-March 2005)) between these parameters. This results from the particle size distribution of the accumulation mode being relatively invariant, as shown by Weingartner et al. (1999), and justifies the use of the scattering coefficient as a PM1 proxy for August 2005.

Figure 9 shows that the two mass fractions present a highly different chemical composition. The PM1 mode is mainly composed of organics and sulfate $\left(\mathrm{SO}_{4}^{2-}\right)$ along with significant fractions of $\mathrm{BC}$, nitrate $\left(\mathrm{NO}_{3}^{-}\right)$, and ammonium $\left(\mathrm{NH}_{4}^{+}\right)$. The non-determined mass (ND) is quite small and is assumed to be composed of insoluble compounds such as silicate from mineral dust. As mentioned previously, the aerosol is sampled at laboratory temperature (i.e. under dry conditions) and the ND fraction is therefore not expected to be explained by condensed water. In contrast, the coarse mode is dominated by the ND fraction. The major determined compound in the coarse mode is calcium $\left(\mathrm{Ca}^{2+}\right)$, which is a known component of mineral dust. The contribution of the measured inorganic compounds is very small, and nitrate seems to be present in the same proportion as sulfate. As shown by Krueger et al. (2004), $\mathrm{NO}_{3}^{-}$can be linked with $\mathrm{Ca}^{2+}$ in the coarse mode by the reaction of mineral dust particles with nitric acid to form $\mathrm{Ca}\left(\mathrm{NO}_{3}\right)_{2}$. Other compounds were not measured (e.g. silica).

The large contributions of $\mathrm{Ca}^{2+}$ on 14 and 20 March (shown in Fig. 9) are due to distinct episodes of Saharan dust over the Jungfraujoch region. These mineral dust episodes were confirmed by the method developed by Collaud Coen et al. (2004), where the wavelength dependence of the single scattering albedo (expressed as the SSA exponent) was found to be an indicator for the presence of dust particles. This exponent becomes negative in the presence of mineral dust. For these two cases the ND fraction in PM1 can be explained by a substantial extension of the coarse mode size distribution into PM1 (Fig. 10), as also shown by Schwikowski et al. (1995).

During March 2004, the ND fraction in PM1 is surprisingly high even when Saharan dust events had been excluded. As can be seen in Fig. 9, this cannot be explained by the pres- 

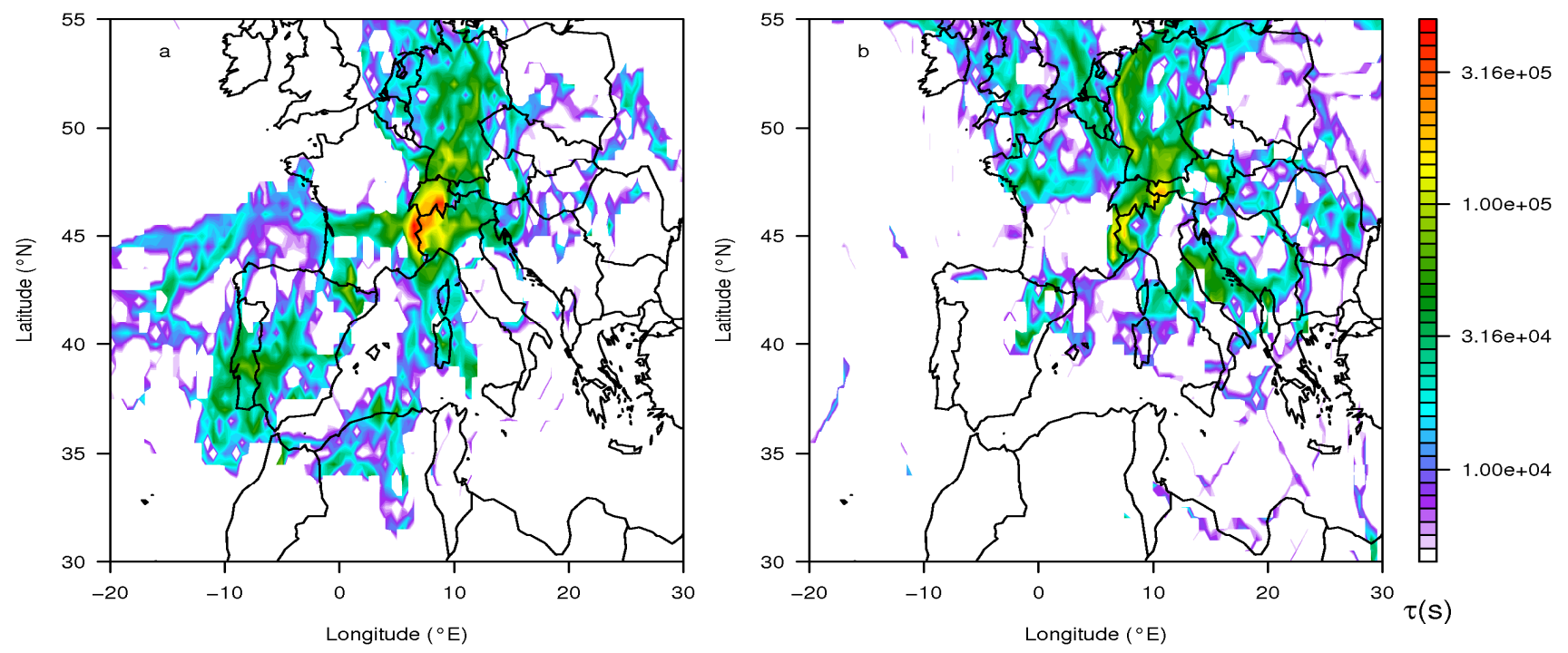

Fig. 11. Trajectory residence time statistics for trajectory points below $1000 \mathrm{~m}$ above ground level for the two periods (a) March 2004 and (b) February-March 2005. Both plots were derived from 900 individual trajectories.

ence of mineral dust since there is no elevated coarse mode and the SSA exponent is not negative. Figure 10 presents two typical volume size distributions from combined SMPS and OPC data during events where continental background aerosol was sampled under conditions that were and were not influenced by mineral dust particles. As explained earlier, the slight discontinuity in the combined number size distribution is likely to result from the difference of the refractive index (and complex morphology) of the measured particles with the spherical Latex particles which are used to calibrate the OPC. No correction was applied as no known calibration factor was available for the ambient aerosol.

The high ND fractions observed in March 2004 were carefully checked for systematic biases. First, the SMPS derived volume concentrations were compared to the measured aerosol light scattering coefficients at $450 \mathrm{~nm}$. As presented above these two parameters showed a very high correlation, and virtually the same ratio $\left(V_{\text {SMPS }} / b_{\text {scat }}\right)$ was determined during March 2004 compared to the other campaigns. This indicates that the aerosol volume is not a critical factor in the unexplained ND fraction. Second, to validate the chemistry data, the $\mathrm{SO}_{4}^{2-}$ measured with the filters was compared with the mass concentration of sulfate determined daily within the Swiss National Air Pollution Monitoring Network by Empa. Particulate sulfate was collected for $24 \mathrm{~h}$ using cellulose filters with a flow rate of $2.5 \mathrm{~L} \mathrm{~min}^{-1}$. The sulfur concentrations were determined with $\mathrm{x}$-ray fluorescence which subsequently were converted to $\mathrm{SO}_{4}^{2-}$ concentrations. A relatively high correlation between the two measured fractions $\left(r^{2}=0.57 ; \mathrm{SO}_{4(\mathrm{PSI})}^{2-}=0.81 \times \mathrm{SO}_{4(\mathrm{EMPA})}^{2-}\right)$ was found which suggests that the concentrations of the filters were correct. Thus, the ND fraction could originate either from an unknown component or from a non-identified problem.
To analyze differences in the air mass origin of the two periods (March 2004 and February-March 2005), backward air mass trajectories were calculated with the trajectory model FLEXTRA (Stohl et al., 1995) based on ECMWF (T511L60) analysis with a horizontal resolution of $1^{\circ} \times 1^{\circ}$. Trajectories were initialized at the JFJ every $4 \mathrm{~h}$, together with 4 other trajectories, which were initialized equidistantly spaced on a circle of $0.25^{\circ}$ radius around the site to assess the uncertainty. The starting altitude was set to the 700-hPa level. Due to the smoothed model topography this level is about $1400 \mathrm{~m}$ above the model ground and about $700 \mathrm{~m}$ below the real station height. However, this starting altitude was found to best represent the larger scale flow conditions at the JFJ.

120-h back-trajectories are shown for the two periods in the two lower panels of Fig. 10. The trajectories were initialized every $4 \mathrm{~h}$ and only the trajectories arriving during the specified measurement period are shown. The different colors represent different arrival times at JFJ, thick trajectories represent the reference trajectories, while thin lines represent uncertainty trajectories. These back-trajectories confirm a potential influence of dust on 13-14 March as the air mass originated close to the surface over the north-western Saharan region. On 6-7 March the air mass came from the UK and across France at an altitude of $>2000 \mathrm{~m}$ a.s.l. and was thus in the free troposphere.

Residence time maps (footprints) were calculated from these trajectories for both periods. Residence times were only evaluated when the trajectory remained close to the surface ( $1000 \mathrm{~m}$ above model ground level) so as to focus on possible surface sources of aerosol. The regions influencing the JFJ as indicated by the residence time maps (Fig. 11) showed distinct differences for the two periods. In general, near surface $(1000 \mathrm{~m}$ above ground level) residence times 


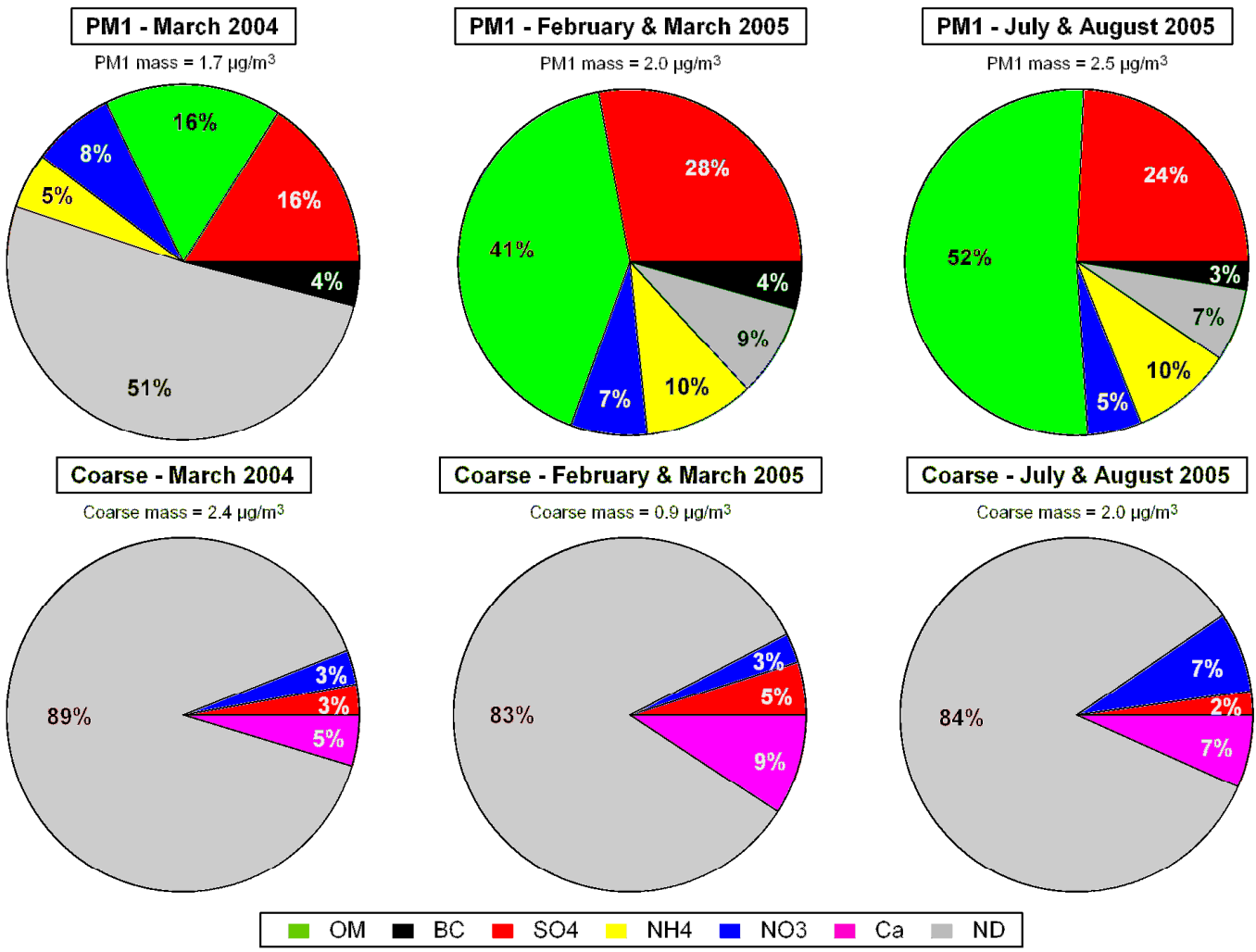

Fig. 12. Mass closure of PM1 and coarse mode for the three campaigns. See text and Table 1 for details on the employed instrumentation.

were increased during March 2004 compared to FebruaryMarch 2005. There was a larger contribution from the western Alpine region and also from the upper Po valley. Furthermore, for 2004 there was a larger contribution from the south especially also from Spain and Algeria, while in 2005 the influence was more from the North. This indicates a potentially enhanced influence of fine mode mineral dust in 2004, which is a likely source of the large unexplained fraction of around $50 \%$.

During 25 February and 10 March 2005, the concentrations of individual species were exceptionally high for the season, and close to summer values when the Jungfraujoch is influenced by injection of PBL layer air into the lower free troposphere. This is also confirmed by an observed scattering coefficient (at $450 \mathrm{~nm}$ ) of $1.2 \times 10^{-5} \mathrm{~m}^{-1}$ compared to the long-term average of $3.2 \times 10^{-6} \mathrm{~m}^{-1}$ (years 1995 to 2006) for this time of the year. The reason for these high concentrations is presently unknown. The contribution of mineral dust to PM1 was small during this period as confirmed by the SSA exponent and OPC size distributions (not shown).

The last campaign presents a summer situation when the site is influenced by the PBL much more frequently. Much higher organic fractions in PM1 were observed than during the winter, as expected since biogenic emissions and photochemistry are enhanced in summer. The PM1 mass shows negative values due to the low signal to noise ratio of the betameter used here since no SMPS data were available.

Figure 12 presents the averages of the chemical composition for the three campaigns as pie charts. These pie charts confirm the highly different composition of fine and coarse mode particles, as well as the higher organic fraction in summer compared to winter. The two winter campaigns are quite different, with a much higher non-determined fraction in PM1 in March 2004. In contrast, February-March 2005 was a period with a much higher concentration of water soluble inorganic species, as outlined above. In March 2004 the mean average concentrations of the fine and coarse mode were $1.7 \mu \mathrm{g} \mathrm{m}^{-3}$ and $2.4 \mu \mathrm{g} \mathrm{m}^{-3}$, respectively, compared with $2.0 \mu \mathrm{g} \mathrm{m}^{-3}$ and $0.9 \mu \mathrm{g} \mathrm{m}^{-3}$ during FebruaryMarch 2005.

\section{Conclusions}

The chemical composition of PM1 and TSP has been measured since 1999 at the Jungfraujoch high alpine site as part of the GAW aerosol program. A clear seasonality in all inorganic compounds was observed with minima in winter typical of the undisturbed free troposphere and maxima in summer where the site is influenced by injections of boundary layer air. In addition, intensive campaigns permitted a chem- 
ical mass closure of PM1 and the coarse mode. These two fractions present highly different chemical composition, with PM1 dominated by organics, sulfate, nitrate, ammonium, BC and the coarse mode composed of mainly calcium and the non-determined fraction, along with minor fractions of nitrate and sulfate. A clear influence of mineral dust episodes was observed in the coarse mode. A conversion factor from $\mathrm{OC}$ to $\mathrm{OM}$ of 1.84 in winter was found, which is within the range of values reported in the literature.

Acknowledgements. We thank the International Foundation High Altitude Research Stations Jungfraujoch and Gornergrat (HFSJG) for the opportunity to perform experiments on the Jungfraujoch. We are grateful to the custodians at Jungfraujoch (Families Staub, Hemund and Fischer) for their inspection and maintenance of instrumentation. The financial support of MeteoSwiss (Global Atmosphere Watch, GAW) is highly appreciated. We thank J. L. Jaffrezo for allowing us to use his ion chromatography facilities at LGGE Grenoble. Parts of the ion chromatography analyses were performed by TERA Environnement, Bernin, France. We thank the UK NERC for the Q-AMS measurements support through research grants NER/A/S/2003/00541, NER/A/S/2001/01135 and NERC studentship NER/S/A/2003/11441.

Edited by: A. Pszenny

\section{References}

Alfaro, S. C., Lafon, S., Rajot, J. L., Formenti, P., Gaudichet, A., and Maille, M.: Iron oxides and light absorption by pure desert dust: An experimental study, J. Geophys. Res., 109, D08208, doi:10.1029/2003JD004374, 2004.

Allan, J. D., Alfarra, M. R., Bower, K. N., Williams, P. I., Gallagher, M. W., Jimenez, J. L., McDonald, A. G., Nemitz, E., Canagaratna, M. R., Jayne, J. T., Coe, H., and Worsnop, D. R.: Quantitative sampling using an aerodyne aerosol mass spectrometer: 2. Measurements of fine particulate chemical composition in two UK cities, J. Geophys. Res.-Atmos., 108(D3), 4091, doi:10.1029/2002JD002359, 2003.

Ayers, G. P.: Comment on regression analysis of air quality data, Atmos. Environ., 35, 2423-2425, 2001.

Bae, M. S., Schauer, J. J., DeMinter, J. T., Turner, J. R., Smith, D., and Cary, R. A.: Validation of a semi-continuous instrument for elemental carbon and organic carbon using a thermal-optical method, Atmos. Environ., 38, 2885-2893, 2004.

Baltensperger, U., Gaggeler, H. W., Jost, D. T., Emmenegger, M., and Nageli, W.: Continuous background aerosol monitoring with the epiphaniometer, Atmos. Environ., 25, 629-634, 1991.

Baltensperger, U., Gäggeler, H. W., Jost, D. T., Lugauer, M., Schwikowski, M., Weingartner, E., and Seibert, P.: Aerosol climatology at the high-alpine site Jungfraujoch, Switzerland, J. Geophys. Res.-Atmos., 102, 19707-19715, 1997.

Baltensperger, U., Schwikowski, M., Jost, D. T., Nyeki, S., Gäggeler, H. W., and Poulida, O.: Scavenging of atmospheric constituents in mixed phase clouds at the high-alpine site Jungfraujoch part I: Basic concept and aerosol scavenging by clouds, Atmos. Environ., 32, 3975-3983, 1998.
Baltensperger, U., Weingartner, E., Burtscher, H., and Keskinen, J.: Dynamic mass and surface area measurements, edited by: Willeke, K. and Baron, P. A., Wiley-Interscience, 2001.

Beig, G. and Brasseur, G. P.: Model of tropospheric ion composition: A first attempt, J. Geophys. Res.-Atmos., 105, 22 671$22684,2000$.

Birch, M. E. and Cary, R. A.: Elemental carbon-based method for monitoring occupational exposures to particulate diesel exhaust, Aerosol Sci. Tech., 25, 221-241, 1996.

Bond, T. C. and Bergstrom, R. W.: Light absorption by carbonaceous particles: An investigative review, Aerosol Sci. Tech., 40, 27-67, 2006.

Canagaratna, M. R., Jayne, J. T., Jimenez, J. L., Allan, J. D., Alfarra, M. R., Zhang, Q., Onasch, T. B., Drewnick, F., Coe, H., Middlebrook, A., Delia, A., Williams, L. R., Trimborn, A. M., Northway, M. J., DeCarlo, P. F., Kolb, C. E., Davidovits, P., and Worsnop, D. R.: Chemical and microphysical characterization of ambient aerosols with the aerodyne aerosol mass spectrometer, Mass Spectrom. Rev., 26, 185-222, 2007.

Charlson, R. J., Lovelock, J. E., Andreae, M. O., and Warren, S. G.: Oceanic phytoplankton, atmospheric sulfur, cloud albedo and climate, Nature, 326, 655-661, 1987.

Cheng, Y. H. and Tsai, C. J.: Evaporation loss of ammonium nitrate particles during filter sampling, J. Aerosol Sci., 28, 1553-1567, 1997.

Chow, J. C., Watson, J. G., Crow, D., Lowenthal, D. H., and Merrifield, T.: Comparison of IMPROVE and NIOSH carbon measurements, Aerosol Sci. Tech., 34, 23-34, 2001.

Colbeck, I.: Physical and chemical properties of aerosols, Blackie Academic \& Professional, London, Weinheim, New York, Tokyo, Melbourne, Madras, 1998.

Collaud Coen, M., Weingartner, E., Schaub, D., Hueglin, C., Corrigan, C., Henning, S., Schwikowski, M., and Baltensperger, U.: Saharan dust events at the Jungfraujoch: detection by wavelength dependence of the single scattering albedo and first climatology analysis, Atmos. Chem. Phys., 4, 2465-2480, 2004, http://www.atmos-chem-phys.net/4/2465/2004/.

Collaud Coen, M., Weingartner, E., Nyeki, S., Cozic, J., Henning, S., Verheggen, B., Gehrig, R., and Baltensperger, U.: Long-term trend analysis of aerosol variables at the high alpine site Jungfraujoch, J. Geophys. Res.-Atmos., 112, D13213, doi:10.1029/2006JD007995, 2007.

Cozic, J., Verheggen, B., Mertes, S., Connolly, P., Bower, K., Petzold, A., Baltensperger, U., and Weingartner, E.: Scavenging of black carbon in mixed phase clouds at the high alpine site Jungfraujoch, Atmos. Chem. Phys., 7, 1-11, 2007, http://www.atmos-chem-phys.net/7/1/2007/.

Evans, R. D.: The Atomic Nucleus, McGraw-Hill, N.Y., 1955.

Finlayson-Pitts, B. J. and Pitts, J. N. J.: Chemistry of the upper and lower atmosphere, Elsevier, New York, 2000.

Fischer, E. V., Ziemba, L. D., Talbot, R. W., Dibb, J. E., Griffin, R. J., Husain, L., and Grant, A. N.: Aerosol major ion record at Mount Washington, J. Geophys. Res.-Atmos., 112, D02303, doi:10.1029/2006JD007253, 2007.

Fisseha, R., Dommen, J., Gutzwiller, L., Weingartner, E., Gysel, M., Emmenegger, C., Kalberer, M., and Baltensperger, U.: Seasonal and diurnal characteristics of water soluble inorganic compounds in the gas and aerosol phase in the Zurich area, Atmos. Chem. Phys., 6, 1895-1904, 2006, 
http://www.atmos-chem-phys.net/6/1895/2006/.

Fuller, K. A., Malm, W. C., and Kreidenweis, S. M.: Effects of mixing on extinction by carbonaceous particles, J. Geophys. Res.Atmos., 104, 15 941-15 954, 1999.

GAW: Aerosol Measurement procedures guidelines and recommendations (September 2003), Tech. Rep. 1178, WMO, Geneva, 2003.

GAW: A Contribution to the Implementation of the WMO Strategic Plan: 2008-2011, Tech. Rep. 1384, WMO, Geneva, 2007.

Gehrig, R. and Buchmann, B.: Characterising seasonal variations and spatial distribution of ambient PM10 and PM2.5 concentrations based on long-term Swiss monitoring data, Atmos. Environ., 37, 2571-2580, 2003.

Henne, S., Furger, M., and Prevot, A. S. H.: Climatology of mountain venting-induced elevated moisture layers in the lee of the Alps, J. Appl. Meteorol., 44, 620-633, 2005.

Henning, S., Weingartner, E., Schwikowski, M., Gaggeler, H. W., Gehrig, R., Hinz, K. P., Trimborn, A., Spengler, B., and Baltensperger, U.: Seasonal variation of water-soluble ions of the aerosol at the high-alpine site Jungfraujoch (3580 m asl), J. Geophys. Res.-Atmos., 108 (D1), 4030, doi:10.1029/2002JD002439, 2003.

Hoffer, A., Gelencser, A., Guyon, P., Kiss, G., Schmid, O., Frank, G. P., Artaxo, P., and Andreae, M. O.: Optical properties of humic-like substances (HULIS) in biomass-burning aerosols, Atmos. Chem. Phys., 6, 3563-3570, 2006,

http://www.atmos-chem-phys.net/6/3563/2006/.

Hueglin, C., Gehrig, R., Baltensperger, U., Gysel, M., Monn, C., and Vonmont, H.: Chemical characterisation of PM2.5, PM10 and coarse particles at urban, near-city and rural sites in Switzerland, Atmos. Environ., 39, 637-651, 2005.

Husain, L., Parekh, P. P., Dutkiewicz, V. A., Khan, A. R., Yang, K., and Swami, K.: Long-term trends in atmospheric concentrations of sulfate, total sulfur, and trace elements in the northeastern United States, J. Geophys. Res.-Atmos., 109, D18305, doi:10.1029/2004JD004877, 2004.

Imhof, D., Weingartner, E., Ordonez, C., Gehrig, R., Hill, N., Buchmann, B., and Baltensperger, U.: Real-world emission factors of fine and ultrafine aerosol particles for different traffic situations in Switzerland, Environ. Sci. Tech., 39, 8341-8350, 2005.

Intergovernmental Panel on Climate Change (IPCC): Climate change 2007: The physical basis of climate change, IPCC Secretariat, Geneva, Switzerland, available at http://www.ipcc.ch, Working Group I, Final Report, available at http://ipcc-wg1.ucar. edu/wg1/wg1-report.html, 2007.

Jaklevic, J. M. and Gatti, R. C.: Beta gauge method applied to aerosol samples, Environ. Sci. Tech., 680-687, 1981.

Jayne, J. T., Leard, D. C., Zhang, X. F., Davidovits, P., Smith, K. A., Kolb, C. E., and Worsnop, D. R.: Development of an aerosol mass spectrometer for size and composition analysis of submicron particles, Aerosol Sci. Tech., 33, 49-70, 2000.

Keene, W. C., Pszenny, A. A. P., Maben, J. R., Stevenson, E., and Wall, A.: Closure evaluation of size-resolved aerosol $\mathrm{pH}$ in the New England coastal atmosphere during summer, J. Geophys. Res.-Atmos., 109, D23307, doi:10.1029/2004JD004801, 2004.

Krivacsy, Z., Hoffer, A., Sarvari, Z., Temesi, D., Baltensperger, U., Nyeki, S., Weingartner, E., Kleefeld, S., and Jennings, S. G.: Role of organic and black carbon in the chemical composition of atmospheric aerosol at European background sites, Atmos. Env- iron., 35, 6231-6244, 2001.

Krueger, B. J., Grassian, V. H., Cowin, J. P., and Laskin, A.: Heterogeneous chemistry of individual mineral dust particles from different dust source regions: the importance of particle mineralogy, Atmos. Environ., 38, 6253-6261, 2004.

Lavanchy, V. M. H., Gäggeler, H. W., Nyeki, S., and Baltensperger, U.: Elemental carbon (EC) and black carbon (BC) measurements with a thermal method and an aethalometer at the high-alpine research station Jungfraujoch, Atmos. Environ., 33, 2759-2769, 1999.

Linke, C., Möhler, O., Veres, A., Mohacsi, A., Bozoki, Z., Szabo, G., and Schnaiter, M.: Optical properties and mineralogical composition of different Saharan mineral dust samples: a laboratory study, Atmos. Chem. Phys., 6, 3315-3323, 2006, http://www.atmos-chem-phys.net/6/3315/2006/.

Liousse, C., Cachier, H., and Jennings, S. G.: Optical and thermal measurements of black carbon aerosol content in different environments - Variation of the specific attenuation cross-section, sigma, Atmos. Environ., 27, 1203-1211, 1993.

Lugauer, M., Baltensperger, U., Furger, M., Gäggeler, H. W., Jost, D. T., Schwikowski, M., and Wanner, H.: Aerosol transport to the high Alpine sites Jungfraujoch (3454 m asl) and Colle Gnifetti (4452 m asl), Tellus B, 50, 76-92, 1998.

Lugauer, M., Baltensperger, U., Furger, M., Gaggeler, H. W., Jost, D. T., Nyeki, S., and Schwikowski, M.: Influences of vertical transport and scavenging on aerosol particle surface area and radon decay product concentrations at the jungfraujoch (3454 m above sea level), J. Geophys. Res.-Atmos., 105, 19 869-19879, 2000.

Maenhaut, W., Hillamo, R., Makela, T., Jaffrezo, J. L., Bergin, M. H., and Davidson, C. I.: A new cascade impactor for aerosol sampling with subsequent PIXE analysis, Nuclear Instrum. Meth B, 109, 482-487, 1996.

Malm, W. C., Schichtel, B. A., Ames, R. B., and Gebhart, K. A.: A 10-year spatial and temporal trend of sulfate across the United States, J. Geophys. Res.-Atmos., 107(D22), 4627, doi:10.1029/2002JD002107, 2002.

Malm, W. C., Schichtel, B. A., Pitchford, M. L., Ashbaugh, L. L., and Eldred, R. A.: Spatial and monthly trends in speciated fine particle concentration in the United States, J. Geophys. Res.Atmos., 109, D03306, doi:10.1029/2003JD003739, 2004.

McMurry, P. H., Wang, X., Park, K., and Ehara, K.: The relationship between mass and mobility for atmospheric particles: A new technique for measuring particle density, Aerosol Sci. Tech., 36, 227-238, 2002.

Petzold, A. and Schonlinner, M.: Multi-angle absorption photometry - a new method for the measurement of aerosol light absorption and atmospheric black carbon, J. Aerosol Sci., 35, 421-441, 2004.

Putaud, J. P., Raes, F., Van Dingenen, R., Bruggemann, E., Facchini, M. C., Decesari, S., Fuzzi, S., Gehrig, R., Huglin, C., Laj, P., Lorbeer, G., Maenhaut, W., Mihalopoulos, N., Mulller, K., Querol, X., Rodriguez, S., Schneider, J., Spindler, G., ten Brink, H., Torseth, K., and Wiedensohler, A.: European aerosol phenomenology-2: chemical characteristics of particulate matter at kerbside, urban, rural and background sites in Europe, Atmos. Environ., 38, 2579-2595, 2004a.

Putaud, J. P., Van Dingenen, R., Dell'Acqua, A., Raes, F., Matta, E., Decesari, S., Facchini, M. C., and Fuzzi, S.: Size-segregated 
aerosol mass closure and chemical composition in Monte Cimone (I) during MINATROC, Atmos. Chem. Phys., 4, 889-902, 2004b.

Ricard, V., Jaffrezo, J. L., Kerminen, V. M., Hillamo, R. E., Sillanpaa, M., Ruellan, S., Liousse, C., and Cachier, H.: Two years of continuous aerosol measurements in northern Finland, J. Geophys. Res.-Atmos., 107(D11), doi:10.1029/2001JD000952, 2002.

Schauer, J. J., Mader, B. T., Deminter, J. T., Heidemann, G., Bae, M. S., Seinfeld, J. H., Flagan, R. C., Cary, R. A., Smith, D., Huebert, B. J., Bertram, T., Howell, S., Kline, J. T., Quinn, P., Bates, T., Turpin, B., Lim, H. J., Yu, J. Z., Yang, H., and Keywood, M. D.: ACE-Asia intercomparison of a thermal-optical method for the determination of particle-phase organic and elemental carbon, Environ. Sci. Tech., 37, 993-1001, 2003.

Schmid, H., Laskus, L., Abraham, H. J., Baltensperger, U., Lavanchy, V., Bizjak, M., Burba, P., Cachier, H., Crow, D., Chow, J., Gnauk, T., Even, A., ten Brink, H. M., Giesen, K. P., Hitzenberger, R., Hueglin, C., Maenhaut, W., Pio, C., Carvalho, A., Putaud, J. P., Toom-Sauntry, D., and Puxbaum, H.: Results of the "carbon conference" international aerosol carbon round robin test stage I, Atmos. Environ., 35, 2111-2121, 2001.

Schwikowski, M., Seibert, P., Baltensperger, U., and Gäggeler, H. W.: A study of an outstanding Saharan dust event at the high-Alpine site Jungfraujoch, Switzerland, Atmos. Environ., 29, 1829-1842, 1995.

Sharma, S., Brook, J. R., Cachier, H., Chow, J., Gaudenzi, A., and Lu, G.: Light absorption and thermal measurements of black carbon in different regions of Canada, J. Geophys. Res.-Atmos., 107(D24), 4771, doi:10.1029/2002JD002496, 2002.

Sirois, A. and Barrie, L. A.: Arctic lower tropospheric aerosol trends and composition at Alert, Canada: 1980-1995, J. Geophys. Res.-Atmos., 104, 11 599-11 618, 1999.

Stohl, A., Wotawa, G., Seibert, P., and Krompkolb, H.: Interpolation errors in wind fields as a function of spatial and temporal resolution and their impact on different types of kinematic trajectories, J. Appl. Meteorol., 34, 2149-2165, 1995.

Turpin, B. J. and Huntzicker, J. J.: Identification of secondary organic aerosol episodes and quantitation of primary and secondary organic aerosol concentrations during SCAQS, Atmos. Environ., 29, 3527-3544, 1995.

Verheggen, B., Cozic, J., Weingartner, E., Bower, K., Mertes, S., Connolly, P., Flynn, M., Gallagher, M., Choularton, T., and Baltensperger, U.: Aerosol activation in mixed phase clouds at the high Alpine site Jungfraujoch, J. Geophys. Res.-Atmos., 112, D23202, doi:10.1029/2007JD008714, 2007.
Virtanen, A., Ronkko, T., Kannosto, J., Ristimaki, J., Makela, J. M., Keskinen, J., Pakkanen, T., Hillamo, R., Pirjola, L., and Hameri, $\mathrm{K}$.: Winter and summer time size distributions and densities of traffic-related aerosol particles at a busy highway in Helsinki, Atmos. Chem. Phys., 6, 2411-2421, 2006, http://www.atmos-chem-phys.net/6/2411/2006/.

Weingartner, E., Nyeki, S., and Baltensperger, U.: Seasonal and diurnal variation of aerosol size distributions $(10<\mathrm{D}<750 \mathrm{~nm})$ at a high-alpine site (Jungfraujoch $3580 \mathrm{~m}$ asl), J. Geophys. Res.Atmos., 104, 26 809-26 820, 1999.

Weingartner, E., Gysel, M., and Baltensperger, U.: Hygroscopicity of aerosol particles at low temperatures. 1. New low-temperature H-TDMA instrument: Setup and first applications, Environ. Sci. Tech., 36, 55-62, 2002.

Zellweger, C., Ammann, M., Buchmann, B., Hofer, P., Lugauer, M., Ruttimann, R., Streit, N., Weingartner, E., and Baltensperger, U.: Summertime NOy speciation at the jungfraujoch, $3580 \mathrm{~m}$ above sea level, Switzerland, J. Geophys. Res.-Atmos., 105, 66556667, 2000.

Zhang, Q., Jimenez, J. L. Canagaratna, M. R., Allan, J. D., Coe, H., Ulbrich, I., Alfarra, M. R., Takami, A., Middlebrook, A. M., Sun, Y. L., Dzepina, K., Dunlea, E., Docherty, K., DeCarlo, P. F., Salcedo, D., Onasch, T., Jayne, J. T., Miyoshi, T., Shimono, A., Hatakeyama, S., Takegawa, N., Kondo, Y., Schneider, J., Drewnick, F., Borrmann, S., Weimer, S., Demerjian, K, Williams, P., Bower, K., Bahreini, R., Cottrell, L., Griffin, R. J., Rautiainen, J. Sun, J. Y., Zhang, Y. M., and Worsnop D. R.: Ubiquity and dominance of oxygenated species in organic aerosols in anthropogenically-influenced Northern Hemisphere midlatitudes, Geophys. Res. Lett., 37, L13801, doi:10.1029/2007GL029979, 2007.

Zhang, X. F., Smith, K. A., Worsnop, D. R., Jimenez, J., Jayne, J. T., and Kolb, C. E.: A numerical characterization of particle beam collimation by an aerodynamic lens-nozzle system: Part I. An individual lens or nozzle, Aerosol Sci. Tech., 36, 617-631, 2002.

Zhang, X. Q. and McMurry, P. H.: Evaporative losses of fine particulate nitrates during sampling, Atmos. Environ., 26, 3305-3312, 1992. 